Article

\title{
Environmental Risk Management for Museums in Historic Buildings through an Innovative Approach: A Case Study of the Pinacoteca di Brera in Milan (Italy)
}

\author{
Elena Lucchi \\ EURAC Research, Politecnico di Milano, 20133 Milano, Italy; elena.lucchi@polimi.it
}

Received: 9 May 2020; Accepted: 22 June 2020; Published: 24 June 2020

\begin{abstract}
In the contemporary age, museums are dealing with unexpected challenges, related to the transformation of social structures, educative methods and cultural diffusion. The conversion of heritage buildings into exhibition halls and the renovation of existent exhibits involve a series of environmental risks and preservation issues. The study aims to demonstrate that conservation and human comfort are mutually compatible, when based on rational planning, interdisciplinary cooperation, and extensive knowledge of the features of buildings and collections. This study carries out an operative strategy for assessing and managing the environmental risks in museum buildings. To validate its suitability, it is applied to the Pinacoteca di Brera in Milan (Italy), an old palace completely reshaped in the 20th century following the typical design concepts of the "Modern Movement of Architecture" (e.g., rational planning, use of innovative technologies and materials, profusion of natural light integrated with artificial lighting, etc.). Several solutions adopted in these years caused both heritage decay and human discomfort. In addition, the insertion of new functions required a complete modification of the original design project. For this reason, the proposed tool supports the environmental risk management connected with these transformations, also defining clear maintenance guidelines, and planning low-engineering and low-impact solutions to satisfy, in a practical way, the daily needs of conservators, heritage authorities and designers. Furthermore, technical skills and the awareness of museum staff has been improved.
\end{abstract}

Keywords: museum buildings; preventive conservation; human comfort; conservation of 20th century buildings; risk management; low-engineering intervention

\section{Introduction}

The care and the enhancement of historic and artistic heritage preserves the memory of a community and assists the social development of a nation. These actions facilitate the diffusion of a "sense" of cultural heritage, and give a social, cultural and economic value to the patrimony [1]. Furthermore, the Council of Europe stated "[ ... ] the need to involve everyone in society in the ongoing process of defining and managing cultural heritage" [2], to encourage the modernization of the sector [2,3]. In this context, cultural heritage plays an important role in sharing a dynamic and proactive notion of cultural services, to attract more public funding, and to create public value [4]. Thus, the museums, traditionally designated for heritage conservation, assume also an educational role for transmitting heritage values, for sharing innovative education approaches, and for promoting touristic activities [4]. The International Council of Museums (hereinafter, ICOM) recognized the social role of the museum [4], introducing a new definition the institution as something "[ ... open to the public, which acquires, conserves, researches, communicates and exhibits the tangible and intangible heritage of humanity and its environment for the purposes of education, study and enjoyment" [1]. Museum architecture anticipated this conceptual shift: the "collision of architecture and culture" [5] changed 
the traditional idea of a "museum" as a "monolithic institution" [6] since the opening of the Pompidou Centre in 1977 [5]. A new notion of the "modern museum" in the Post-Pompidou Age arose [5], as a dynamic concept based on multi-disciplinary functions and continuously transforming spaces [5]. Close to the traditional structures deputed to preservation, research and exhibition, new leisure facilities were inserted to host educational functions, didactic rooms, amusement spaces, bookshops, conference rooms, libraries, shops, cafeterias and restaurants $[4,5,7,8]$. Nowadays, the museums acquire also the tasks of environmental sustainability, the reduction of greenhouse gas emissions, and energy efficiency [9-11]. The conversion of listed buildings (i.e., palaces, castles, and so on) into exhibition spaces, and the renovation of the existent exhibits, involves adjunctive environmental risks $[9,10]$. Environmental quality in museum buildings depends on achieving the right balance between several complex and frequently contradictory aspects, such as: public enjoyment, touristic entertainment, communication, indoor climate control, users' comfort, display, preservation, energy savings and safety precautions [11,12]. The traditional logic of "restoration", where the effects of decay are repaired and reinforced by invasive interventions [13], was gradually abandoned to adopt the idea of "prevention" [14] of damages and risks. The discipline of preventive conservation departs from this idea, trying to balance these complex aspects [14,15]. It is defined as a process of "[ ... ] non-interventive actions taken to prevent damage and minimize deterioration of a museum object" [16]. This approach fosters a logic of long-term interventions, based on "[ ... ] modest maintenance actions repeated over time" [17] or "[ ... ] regular and permanent maintenance" [18]. Its focus moves from the collection or from the historical object, to the context surrounding the heritage $[13,19,20]$. The international standards are making progress in this direction, establishing the optimal environmental levels for reducing the indoor climate risks related to light, air temperature, relative humidity and pollutant concentration [21-23]. Initially, only the decay caused by a single parameter was considered [11,14,24-29]. Later, their cumulative effects [12] and their impact on human comfort [30] were taken into account. Several standards defined the environmental levels for reducing decay [31-39]. Numerous cultural institutions concerted these standards in guidelines and policies for environmental management, adapting their practical experiences to the variety of heritage features and local rules [14,15,40-47]. The American Society of Heating, Refrigeration and Air-Conditioning Engineers (hereinafter, ASHRAE) handbook [48] changed completely the traditional logic of environmental risk management based on the respect of severe indoor conditions. It specified the environmental climatic ranges for four "museum climate classes", referring to the characteristics of the buildings, the collections and the systems (Section 4.2). These specifications were not prescriptive, but this theory remarked on the importance of the environmental design and risk management [49]. Elsewhere, the European (hereinafter, EU) Committee CEN/TC 346 [50] provided a systematic procedure for preserving artworks, as well as controlling the environmental variables, and implementing energy efficiency, environmental sustainability and human comfort. In parallel, the "New Orleans Charter for the Joint Preservation of Historic Structures and Artefacts" defined the environmental parameters to be utilized for reducing the risks of damage during the transformation of a historic building into a museum [51,52]. The discussions confirm the ASHRAE approach: "[ ... ] the value of conservation approaches based on flexible, relevant principle rather than on fixed standards" [51]. The International Centre for the Study of Preservation and Restoration of Cultural Property (hereinafter, ICCROM) published a guide to facilitate the risk management in cultural heritage [53], starting from an understanding of the environmental, socio-cultural, economic and legal contexts. The procedure was based on several steps, referred to as identification, evaluation, treatment and the monitoring of risks (for a detailed discussion and a comparison with the present methodology see Section 2) [53]. Further, a recent book concerns the decision-making process for assisting collection managers and caretakers in the management of climate risk in museums and historic houses [54]. This process consists of nine steps: (i) development of clear objectives; (ii) evaluation of the significance of the building and the movable collection; (iii) assessment of the climate risks to the movable collection; (iv) identification of the valuable part of the building; (v) identification of the 
human comfort needs for visitors and staff; (vi) building physics exploration; (vii) weighting of the climate specifications; (viii) definition of the options to optimize the indoor climate; (ix) definition of the options to reduce the climate collection risks. The scientific literature proposes different models for assessing the environmental risks. Overall, these approaches require technical support for helping museum curators during the assessment. Two typologies of study are realized: analytical calculations and simulation models. Analytical calculations refer mainly to the introduction of different indices for climatic risk, that balance conservation and human comfort [55-63]. Otherwise, dynamic building energy models support the risk assessments used to quantify the problems [64-66]. In both cases, indoor monitoring data are used for validating the study $[57,59,62-66]$. These approaches require specialized skills, high costs, and long evaluation times [58,67]. For this reason, they are not easily applicable by the museum staff (e.g., curators, archivists, collection managers, conservators) for daily management. On the contrary, these models necessitate the support of professional consultants, such as environmental auditors, building simulators, and so on.

\section{Aim of the Study}

This research aims at establishing an innovative procedure for the environmental risk assessment and management of multifunctional museums located in historic buildings, and to organize the interventions efficiently, economically and durably. This operative procedure is based on the Screening, Observation, Analysis, and Expertise (SOBANE) strategy, a strategic approach to risk assessment and management [56] adopted also by the ICCROM Guide [53] and the standard ISO 31000 [67]. This methodology derives from the evaluation of occupational health at work. Here, it outlines practical prevention measures based on workers' effectiveness and satisfaction [56]. It is particularly useful for making risk prevention faster, ensuring cost reduction and procedure efficiency, and includes the contributions of the workers. For this reason, this general approach is also suggested by the standard ISO 31000 [67] for risk management. Similarly, the ICCROM [53] applies this scheme to risk management for heritage preservation. In this case, the risks vary from sudden and catastrophic events (i.e., earthquakes, floods, fires, and armed conflict) to cumulative processes (i.e., chemical, physical, or biological degradation). The ICCROM scheme somewhat complexifies the SOBANE strategy, introducing the following phases: (i) analysis of the context; (ii) identification of the risks; (iii) analysis of the information sources; (iv) evaluation of the magnitude of risks; (v) treatment of risks; and (vi) monitoring of the results. Compared to the SOBANE strategy, phases (i) and (ii) refer to "screening", phases (iii) and (iv) to "observation", phase (vi) to "analysis", and phases (v) and (vi) to "expertise". Here, general suggestions and examples are given, to be applied in a whole range of cultural heritage elements, ranging from a book to a sculpture, a museum collection, a fresco, a building, an archeological site, a cultural landscape, and so on. Furthermore, the aspects related to human comfort are not considered. In another case, a book helps collection managers in the decision process regarding climate risks [54]. This procedure is quite complex for autonomous adoption by the museum attendants because several steps (e.g., building physics exploration, weighting of the climate specifications) require specialized technical skills. Thus, museum attendants need the support of designers, architects, engineers and building simulators to apply this methodology to a real case study. Otherwise, this procedure evaluates only theoretical levels of human comfort, excluding the perception of uses connected with questionnaires and interviews. Finally, the procedure must be adapted to each local legislative framework, and each set of heritage features, internal policies and procedures.

As introduced before, the present study defines a specific SOBANE strategy for the management of environmental risks in the museums hosted in historic buildings, considering both conservation and human comfort issues (Section 4) [55,56]. The original SOBANE strategy is improved, combining a series of cross-disciplinary elements, based on standards, policies, guidelines, procedures, best-practices and tools for balancing preventive conservation [11,12,15,16,25,29,32,33,36-38,40-44,46,52,68], environmental sustainability $[27,66]$ and human comfort $[48,55]$. The new concept and the needs of the contemporary museums are considered. For this purpose, this instrument is developed with the direct 
support of the museum attendants (e.g., conservators, heritage authorities and curators), to refine their skills and to satisfy their daily needs in optimizing the decision-making purposes, prioritizing the interventions and lowering internal costs [55]. The museum staff are explicitly asked not to consider complex simulations or calculation tools for reducing specialized skills, costs, and evaluation times. This new methodology brings the following benefits: (i) to prolong the lifetime of cultural heritage objects, collections, and buildings; (ii) to evaluate the indoor environmental performances; (iii) to optimize the preventive conservation actions; (iv) to recognize the risks for heritage preservation and human comfort; (v) to assist the decision makers during refurbishment and management interventions; (vi) to define suitable maintenance and management procedures; and (vii) to minimize the economic costs. This approach is applied to the Pinacoteca di Brera in Milan (Italy), to validate its suitability and its applicability in a real case study (Section 3).

\section{The Case Study: Pinacoteca di Brera}

The Pinacoteca di Brera in Milan is one of the most important national fine art museums in Italy (Figure 1a). It expresses well the situation of a national museum inserted in a historic building and converted into an expositive center. The museum is sited in the center of Milan, a city characterized by a "multi-pollutants situation" [29]. It is housed in a medieval building, which has undergone several changes and expansions over the centuries [69-71]. To understand the current situation, it is important to introduce a brief history of its transformation. The name "Brera" derives from the word "braida", which indicates the green area where the original building was erected as a convent and a church (1178). After its expropriation, the old convent became first a "Collegium" for young people's education, and later, a University (1571) [70]. A new building was added to host new functions. The construction was assigned to different famous Italian architects (Martino Bassi, 1591; Francesco Maria Richini, 1615-1658; Giuseppe Piermarini, 1779-1780) [70] who gave both a Baroque and a Neoclassic style. Its cultural function was improved thanks to the Empress Maria Teresa of Austria (1773) who included several institutions, such as an astronomical observatory, a library (Biblioteca Nazionale Braidense), a research center (Istituto Lombardo di Scienze e Lettere), an Academy of Arts (Accademia di Brera), a botanical garden and an art gallery (Pinacoteca di Brera) [69]. The presence of the Academy of Fine Art influenced particularly the establishment of the Pinacoteca, a fine art museum open upon request of the public for assisting academic students as a complement to training activities (1789) [69]. The collection of paintings increased thanks to the Napoleonic expropriations, as well as legacies, donations and bequests. This required a complete reorganization of the gallery (Andrea Appiani, 1807) [69]. In 1882, the Pinacoteca became independent from the Academy. For this reason, several interventions were implemented to give it a modern image (Piero Portaluppi, 1934), including [71]: (i) construction of a warehouse and a photo archive; (ii) opening of the original skylights, circular windows and canopies to have natural light; (iii) closure of all the windows (except those placed in the entrance corridor); (iv) chronologic re-organization of the collection; and (v) renovation of the exhibits. During the Second World War, the roof was destroyed, and few floors were smashed (1943). Thus, the post-war restoration (Piero Portaluppi, 1946-1950) foresaw several interventions according to the principle of the Modern Movement of Architecture, such as: (i) static consolidation of the building; (ii) reorganization of the exhibition and the offices; (iii) reconstruction of the original environmental of the Mocchirolo Chapel; (iv) painting of the walls with a bright coating; (v) refurbishment of the bombarded roof through the insertion of reinforced concrete instead of wooden trusses; (vi) insertion of curtains and skylights to allow natural light; (vii) addition of artificial lighting systems above the curtains; (viii) insertion of radiant panels into the floors; and (ix) selection of rare and precious materials (e.g., marble for floors, plinths, door jambs and internal columns). In the same years, a "comb gallery" was designed to host the temporary exhibition (Franco Albini, 1946-1950) [71]. The lack of maintenance funds caused a general decay (e.g., water infiltration from the roof, safety problems on electrical systems and wall cracking) [70]. The gallery was closed to the public (1974), and reopened to host new functions (e.g., a bookshop in the hall, a bar in the lodge, two climate control storages and 
the offices for the Heritage Authority) (Alberico and Ludovico Belgiojoso, 1978) [71] (Figure 4). Then, the existing curtains and skylights were replaced with glass-chambers and UV-filters (Gregotti and Associates, 1985-1991) [71]. Finally, natural and artificial light were integrated through the insertion of electronic regulators and metal halide lamps (Piero Castiglioni, 1985-1991). An air conditioning system was installed only in the Napoleonic salons (Paolo Gasparini, 1990) [71].

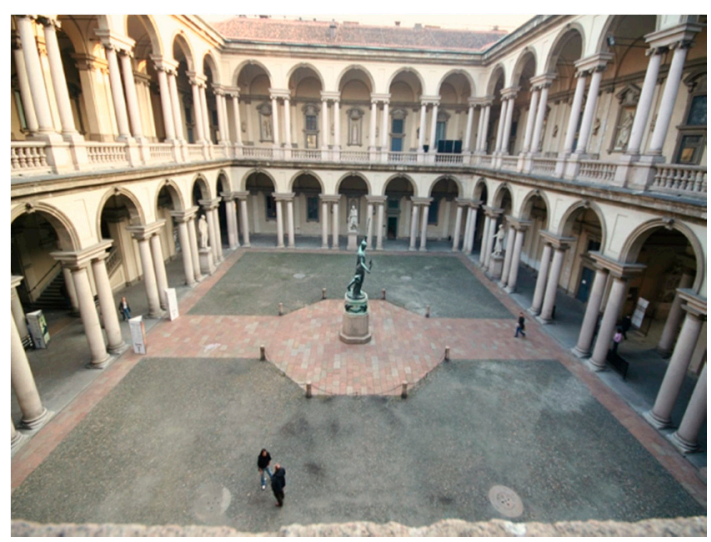

(a)

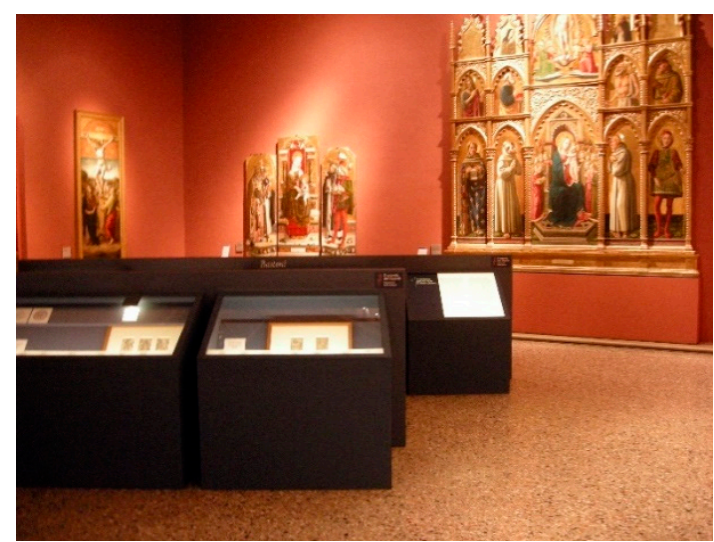

(b)

Figure 1. The Pinacoteca di Brera in Milan: (a) outside view; (b) inside view of the permanent exhibition.

The art collection contains works of several Italian artists (e.g., Raphael, Caravaggio, Andrea Mantegna, Giovanni Bellini, Tiziano, Veronese, Giovanni Fattori and Canaletto) as well as of foreign painters (e.g., El Greco, Rubens, Van Dyck and Rembrant) (Figure 1b). The collection is made upof precious paintings (oil, gouache and pencil on wood, textile and paper) and sculptures (wood and wax), from Gothic to Modern epochs (Figure 4). Their conservation requires severe, non-homogeneous and constant indoor conditions (Table 3). The modifications realized over the centuries led to a complex situation that has necessitated the definition of a risk management strategy, to balance the need of preventive conservation and human comfort. The museum is selected because it is representative of different aspects typical of complex international museums, such as: (i) location in a city with a multi-pollutant situation; (ii) listed building converted into museum; (iii) presence of different architectonical stiles, building features, constructive techniques and materials; (iv) multifunctional spaces (e.g., museum, library, university, bookshop, etc.) and activities (e.g., conservation, restoration, didactics, cultural events, etc.); (v) coexistence of historical and new exhibits and display cases; (vi) important national collection with different typologies of artefacts; and (vii) high fluctuations of visits. This complex situation requires a preventive conservation and human comfort program, to optimize the decision-making processes, and to prioritize the problems.

\section{Methodology}

The SOBANE strategy for environmental risk management in museum buildings is based on four levels of intervention [55]:

- "Screening", a quick diagnosis of the building and the collection for identifying the most important potential risks;

- "Observation", a general study for recognizing causative factors and correlated environmental risks, and for planning simple solutions to solve urgent injuries;

- "Analysis", an instrumental inspection of heritage conservation and human comfort for quantifying potential damage, microclimatic problems and causes of risks;

- "Expertise", a systematic study for developing appropriate guidelines to prioritize the interventions. 
At the end of each level, the operative staff decide whether to pursue the investigations at the subsequent level. As introduced before (Section 2), this method is applied to the Pinacoteca di Brera, to plan simple retrofit and maintenance strategies. The methodology is detailed below (Figure 2).

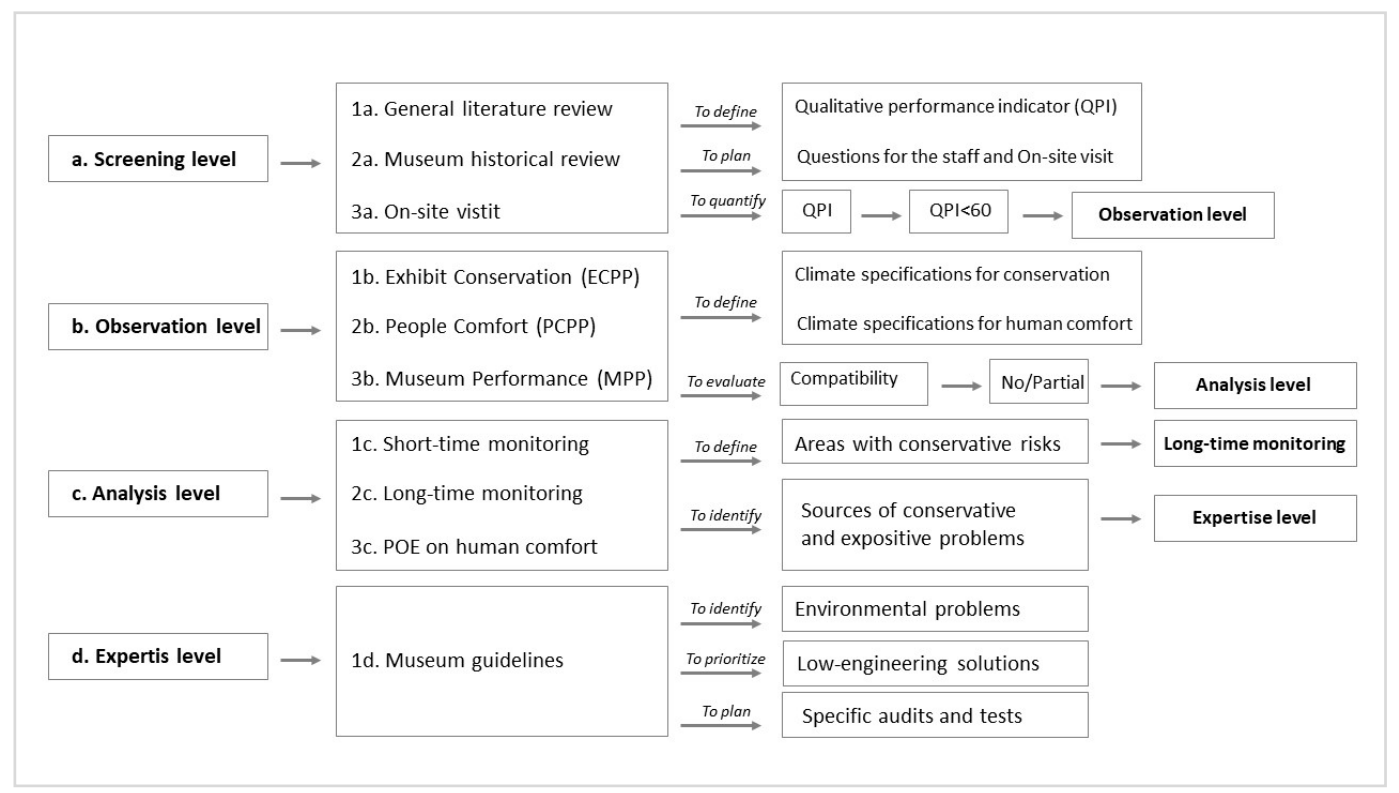

Figure 2. The SOBANE methodology for assessing the environmental risk in the museum buildings.

\subsection{Screening Level}

The "screening level" is a general diagnosis of the building and the collection, for identifying the potential environmental risks. The methodology is founded on the performance indicator system method [55,68], which considers 100 parameters dedicated to heritage conservation, energy efficiency and human comfort. The final score identifies a "qualitative performance indicator" (hereinafter, QPI) based on the presence or the absence of an element [68]. The parameters to be evaluated for assessing the environmental and energy quality in museum buildings include: (i) respect of standards for preventive conservation and human comfort (i.e., light level control, separate light control, UV and/or IR radiation control, strategies of annual energy exposition control, air temperature and/or relative humidity control); (ii) catalysts (i.e., light, temperature, dust); (iii) glare (i.e., direct or reflected glare control); (iv) colors (i.e., study of temperature of light sources, color rending index $>80$, efficacy of chromatic design for users); (v) pollutants (i.e., control strategies for atmospheric and indoor contamination, pests control strategies); (vi) sound (i.e., control of sound and noise); (vii) indoor monitoring systems; (viii) buildings envelope and features (i.e., passive strategies, solar orientation, building shape, wind orientation); (ix) heating, ventilation and air conditioning (hereinafter, HVAC) and electric systems (i.e., control of efficiency of HVAC, electrical and/or lighting systems); (x) renewable energy sources (i.e., photovoltaics or solar thermal systems); (xi) energy policies (i.e., energy label); (xii) maintenance and management procedures (i.e., handling, storage, transport, cleaning, control of free access, integrate pests management, emergency); (xiii) trainings (conservation, energy efficiency); and (xiv) public involvement (i.e., information programs for visitors). The evaluation of these parameters is supported by the literature review and on-site visits with the museum staff. First, the historical review permits us to plan the visit and to define several questions for recognizing the most important environmental risks. Then, the on-site visit with the museum staff gives the data for the QPI calculation. The final QPI is structured into four levels: (i) initial level with a score $<30 \%$; (ii) intermediate level with a score between $30 \%$ and $60 \%$; (iii) good level with a score between $61 \%$ and $90 \%$; (iv) and excellent level with a score $>90 \%$. The buildings with "initial" or "intermediate" levels require more detailed analysis, referred to as the "observation level" (Section 4.2). 


\subsection{Observation Level}

The "observation level" must be applied only to buildings with low energy and environmental performances $(<60 \%)$. This evaluation scheme is a general risk assessment of the indoor climate, according to the Standard EN 15759 [37]. It is structured in three phases [55]: (i) the "Exhibit Conservation Performance Program" (hereinafter, ECPP) that recognizes risk types and agents of deterioration for ensuring the preservation of buildings and collections, ranking their relative importance; (ii) the "People Comfort Performance Program" (hereinafter, PCPP) that outlines the microclimatic standards for human comfort; and (iii) the "Museum Performance Program" (hereinafter, MPP) that identifies the areas with environmental risks, defining a possible balance between conservation and comfort requirements.

The ECPP considers historical and actual indoor climates (called also "climate specifications for conservation") [55]. Regarding the "historical indoor climate", heritage buildings and collections adapt themselves to long-term acclimation processes, as demonstrated by the standard EN 15757 [35]. Similarly, several objects are also preserved in unheated conditions (e.g., churches or old palaces) or with hygrothermal fluctuations [52]. Thoughtfully, the "historical indoor climate" is not harmful for the preservation of artworks [37,52]. Thus, it is not considered in the present methodology. The definition of the "climate specifications for conservation" considers the response of the building and the collection to the actual environmental conditions, as request by the "New Orleans Charter" [51]. The response of the building to the environment refers to the "building classes", defined by the ASHRAE [48] for distinguishing the environmental fluctuations during natural seasonal variations (Table 1). In opposite to the traditional logic that requires severe indoor conditions for avoiding climate risks, the ASHRAE introduces specifications for short-term fluctuations, long-term fluctuations, and permissible levels of indoor dry bulb air temperature $\left(\mathrm{T}_{\mathrm{a}}\right)$ and air relative humidity $(\mathrm{RH})$. This handbook presents four "museum climate classes", ranging from Class AA (precision control) to Class D (relaxed control), related to the fragility of the artifacts. These progressive "categories of control" are defined for each "building class" according to the building features (i.e., typical building construction, type and use) and system characteristics (i.e., system used, limits of the climate control) [48]. Each class corresponds to specific ranges of $\mathrm{T}_{\mathrm{a}}$ and $\mathrm{RH}$ naturally provided by the building (Table 1 ). Data to be analyzed for defining the "building classes" are [55]: (i) history of the museum (e.g., age, additions, refurbishments); (ii) constructive features (e.g., localization, owner, typological, structural, dimensional and constructive data); (iii) conservative conditions (e.g., restorations, potential damage); (iv) indoor activities (e.g., photographic laboratories, bookshop, shops); and (v) maintenance procedures (e.g., handlings, cleaning, preservation, restoration, maintenance programs) and management policies (e.g., use, level of use, level of accessibility, opening times, number and frequency of visitors). Besides, assessing the response of the collection to the environment refers to a detailed knowledge of the type of artifacts (e.g., reference codes, localization, hierarchy, historical data), the conservative conditions, the management policies (e.g., care, display and storage procedures), and the standard levels for heritage conservation. In parallel, the PCPP evaluates the microclimatic conditions for human comfort in museum, referring to the existing literature and standards [39,41,52]. Finally, the data collected are compared in the MPP, to verify the possible compromises between the opposite exigencies for caring and valorizing cultural heritage. MPP considers the following environmental parameters: light level (E), maximum annual energy exposition (EE), maximum ultraviolet radiation $\left(\mathrm{UV}_{\max }\right)$, daylight factor $(D F)$, glare index $(G)$, color temperature index $\left(T_{I}\right)$, color rendering index $\left(R_{a}\right)$, indoor $T_{a}$, mean radiant temperature $\left(T_{m r}\right)$, operative temperature $\left(T_{o}\right)$, surface temperature $\left(T_{s}\right)$, indoor $R H$, temperature difference $(\Delta \mathrm{T}), \mathrm{RH}$ difference $(\Delta \mathrm{RH})$, air velocity $\left(v_{\mathrm{a}}\right)$, indoor concentration of pollutants (gases and solid), and air-changes (r). The range for each parameter refers to actual standards for heritage conservation and human comfort in museum buildings [32,33]. Three levels of compatibility are recognized: (i) full compatibility; (ii) partial compatibility; and (iii) incompatibility. A more in-depth diagnosis and monitoring ("analysis level", Section 4.3) is necessary in the last two cases 
to discover the causes of risks, to establish a possible interrelationship among the problems, and to propose appropriate interventions.

Table 1. Potential "building classes" of "climate control" in the Pinacoteca di Brera: scheme elaborated from the ASHRAE Handbook [48].

\begin{tabular}{|c|c|c|c|c|c|c|c|}
\hline $\begin{array}{l}\text { Category } \\
\text { of Control }\end{array}$ & $\begin{array}{l}\text { Building } \\
\text { Class }\end{array}$ & $\begin{array}{c}\text { Building } \\
\text { Construction }\end{array}$ & $\begin{array}{l}\text { Type of } \\
\text { Building }\end{array}$ & $\begin{array}{l}\text { Building } \\
\text { Use }\end{array}$ & System Used & $\begin{array}{l}\text { Limit of } \\
\text { Climate } \\
\text { Control }\end{array}$ & $\begin{array}{c}\text { Class of } \\
\text { Possible } \\
\text { Control }\end{array}$ \\
\hline $\begin{array}{l}\text { Partial } \\
\text { control }\end{array}$ & IV & $\begin{array}{l}\text { Heavy } \\
\text { masonry or } \\
\text { composite } \\
\text { walls with } \\
\text { plaster } \\
\text { Tight } \\
\text { construction, } \\
\text { storm } \\
\text { windows }\end{array}$ & $\begin{array}{l}\text { Finished } \\
\text { house, } \\
\text { church, } \\
\text { meeting } \\
\text { house, store, } \\
\text { inn, some } \\
\text { office, } \\
\text { buildings }\end{array}$ & $\begin{array}{l}\text { Staff isolated } \\
\text { rooms, gift } \\
\text { shops. } \\
\text { Walk-through } \\
\text { visitations } \\
\text { only. } \\
\text { Limited } \\
\text { occupancy. } \\
\text { No winter } \\
\text { use }\end{array}$ & $\begin{array}{l}\text { Ducted } \\
\text { low-level heat, } \\
\text { Summer } \\
\text { cooling, on/off } \\
\text { control, DX } \\
\text { cooling, some } \\
\text { humidification, } \\
\text { reheat } \\
\text { capability }\end{array}$ & Basic HVAC & $\begin{array}{l}\text { B (if } \\
\text { benign } \\
\text { climate) } \\
\text { C (if mild } \\
\text { winters) } \\
\text { D }\end{array}$ \\
\hline $\begin{array}{l}\text { Climate } \\
\text { controlled }\end{array}$ & VI & $\begin{array}{l}\text { Metal wall } \\
\text { construction, } \\
\text { interior rooms } \\
\text { with sealed } \\
\text { walls and } \\
\text { controlled } \\
\text { occupancy }\end{array}$ & $\begin{array}{l}\text { Vaults, } \\
\text { storage } \\
\text { rooms, cases }\end{array}$ & $\begin{array}{l}\text { No } \\
\text { occupancy, } \\
\text { access by } \\
\text { appointments }\end{array}$ & $\begin{array}{l}\text { Special } \\
\text { heating, } \\
\text { cooling, } \\
\text { and humidity } \\
\text { control with } \\
\text { precision } \\
\text { constant } \\
\text { stability } \\
\text { control }\end{array}$ & $\begin{array}{l}\text { Special } \\
\text { constant } \\
\text { environments }\end{array}$ & $\begin{array}{l}\text { AA } \\
\text { A } \\
\text { Cold } \\
\text { Cold } \\
\text { Dry }\end{array}$ \\
\hline
\end{tabular}

\subsection{Analysis Level}

The "analysis level" is based on the instrumental investigation of the indoor environmental conditions, to identify and to rank the potential sources of conservative and expositive problems, through the correlation between current damage and microclimatic ranges. It is structured in the following phases [55]: (i) short-term monitoring (hereinafter, STM) using spot measuring devices for underlining the areas with environmental risks; (ii) identification of "areas with potential conservative risks"; (iii) long-term monitoring (hereinafter, LTM) using continuous recording devices in the areas at risks; and (iv) analysis of users' comfort.

STM refers to the entire museum. To seek the existence of spatial gradients, it is implemented on a horizontal $(5 \mathrm{~m})$ and vertical $(1.5 \mathrm{~m})$ grid [32]. The minimum indoor parameters to be monitored are light (E, $\mathrm{UV}_{\max }$, infrared radiance), temperature $\left(\mathrm{T}_{\mathrm{a}}, \Delta \mathrm{T}\right)$, and $\mathrm{RH}(\mathrm{RH}, \Delta \mathrm{RH})$. In this case, low-costs and high accuracy devices are used, to be accessible for the museum technicians (Almemo ${ }^{\circledR} 28909-9$ data logger, equipped with light a flux FLA603LSM4 probe, a luminance FLA603LDM2 probe, and a hygrothermal digital sensor FHAD 46-C2). All the minimum indoor parameters are monitored. The sensors are positioned far from heat sources (e.g., incidence of solar radiation, windows, technical appliances), and air flows (e.g., doors, windows, movement of visitors). Direct contact with internal surfaces is also avoided. STM is repeated during winter and summer, to verify the seasonal gradients and the deviation between actual indoor conditions and standards ranges. The presence of spatial gradients higher than the maximum standard value $\left(\Delta \mathrm{T}_{\max }<2{ }^{\circ} \mathrm{C} ; \Delta \mathrm{RH}_{\max }<5 \%\right)$ identifies "areas with potential conservative risks" [32]. These areas are highlighted graphically in a "conservative map". Here, a LTM is conducted for three years, to individuate the causes of environmental vulnerability. LTM monitors the following parameters: light (E, luminance), temperature (outdoor and indoor $\mathrm{T}_{\mathrm{a}}$, daily and seasonal $\Delta \mathrm{T}$ ), $\mathrm{RH}$ (outdoor and indoor $\mathrm{RH}$, daily and seasonal $\Delta \mathrm{RH}$ ), and air quality (carbon dioxide $\mathrm{CO}_{2}$, air change rate, number of visitors). The same acquisition system of the STM is used. The campaign is conducted during summer (June-July), autumn (October-December) and winter (January-February) for two years. The timestep acquisition is 30 minutes, as defined by the standards [32,33]. E is monitored for several typical days during the museum opening (8.30-18.30). 
Luminance is evaluated from specific points of view for the observer on the same days (i.e., in front of a paintings or exhibits). Similarly, $\mathrm{CO}_{2}$ concentration is analyzed during two typical opening days (weekend during the year and holidays), with a timestep of 1 hour. $\mathrm{CO}_{2}$ concentration is not observed during the closing day (Monday) because it is only a comfort indicator, not a damage indicator [29]. The comfort analysis is conducted via interviews with three categories of users (museum staff, single visitors and groups) for evaluating the satisfaction of users regarding climate perception [72]. Several "structured questions" are defined to have an overview of visual (e.g., daylight design, artificial lighting design, discomfort glare, color design), hygrothermal (e.g., thermal levels, hygrometric level, hygrothermal variations), and acoustic comfort (e.g., sound level, acoustic design), as well as of air quality (e.g., presence of contaminants, dust, pests). Then, specific suggestions from people are considered (Section 5.3).

\subsection{Expertise Level}

The "expertise level" is focused on solving specific environmental problems with low-energy and low-impact strategies, mainly related to maintenance, management and low-cost interventions for balancing heritage conservation and human comfort requirements [55]. The results obtained in the previous steps are synthetized in specific guidelines for museum staff and visitors. Besides, specific audits and tests to be planned are defined to quantify complex environmental risks.

\section{Results and Discussion}

The results of this study in the Pinacoteca di Brera are reported below, divided for each phase.

\subsection{Screening Level}

This screening is conducted as a three-hour "guided tour" in the Pinacoteca, with the support of the staff (director, restorers and general staff). A previous literature review on the history of the museum, from the architectonic and artistic points of view, permits us to plan the on-site visit. The QPI is analyzed by the auditor during this visit. The screening is documented through a photographic campaign. The Pinacoteca obtains an intermediate performance $(50.0 \%)$, with an environmental quality of $52.9 \%$ and an energy quality of $43.3 \%$. Light quality (50.0\%) testifies the importance of natural light for Italian postwar museums, but also the difficulties of upgrading the project to new requirements. The hygrothermal (50.0\%) and air (58.8\%) quality shows the difficulty of obtaining indoor stability and air pollutants control, also using HVAC systems. Acoustic quality is not important (33.3\%). The results are reported below (Figure 3).

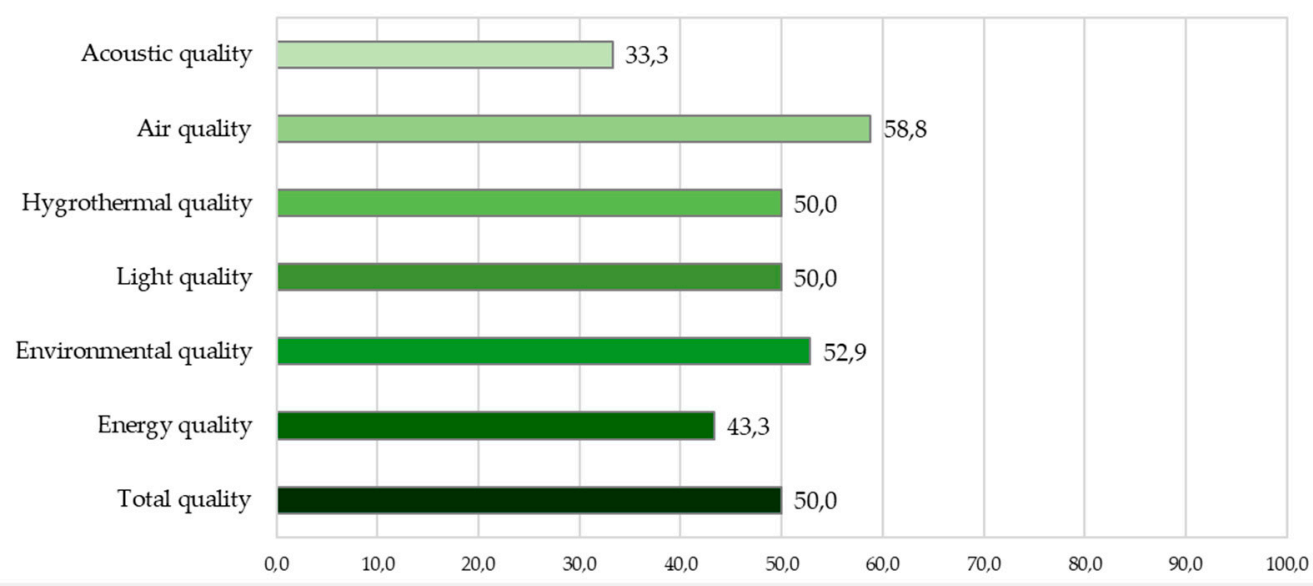

Figure 3. Evaluation of energy and environmental quality in the Pinacoteca di Brera using the performance indicators system. 
The total quality is lower than $60 \%$, and the Pinacoteca is scored as "intermediate level", requiring a more detailed analysis to evaluate its potential environmental risks (Section 5.2).

\subsection{Observation Level}

The ECPP is based on a deep study of architectonical, artistic and operative data, to delineate the response to the building and the collection to the actual environmental conditions. Data analyzed for the Pinacoteca refers to museum history, constructive features, conservative conditions, internal activities, maintenance and management programs. First, deep historical research is conducted to study the evolution and the consistency of the Pinacoteca since its foundation. This information is integrated with the constructive features and the conservative conditions of the building and the collection, referring to the National Center for Documentation (SIRBec-Sistema Informativo dei Beni Culturali di Regione Lombardia) [73] which registers the most important information on local heritage. Additional data on conservative conditions, indoor activities, fruition and management policies are provided by the museum staff. From this information, the ASHRAE potential "category of control" for each "building class" [48] is defined for the Pinacoteca (Table 1).

There is a large difference in the climate conditions of the museum and the storage room. Storage rooms are in safety conditions, protected by passive (e.g., sealed walls, occupancy control) and active (e.g., dedicate HVAC control) measures. This situation corresponds to the ASHRAE building class VI (climate controlled), with possible classes of "climate control" AA, A, Cool, Cold or Dry [48]. On the contrary, museum rooms have partial climate control, with a contrast between building features, uses and HVAC systems. This situation corresponds to the ASHRAE building class IV (partial control), with possible classes of "climate control" B, C, or D [48]. In fact, the museum is located in an old palace with several heritage constraints. The original building was transformed into a museum without guaranteeing a strict indoor climate control (Section 3). The risks are improved by the complex building functions (Figure 4a) (Section 3). In addition, the Pinacoteca is an important Italian museum, with high fluxes of visits (more than 400,000 persons per year, an average of 1,100 persons per day), scholar education programs and touristic activities. Furthermore, the museum collection is classified into homogeneous typologies of objects, related to their inherent sensitivity and vulnerability defined by conservation standards [35-38] (Figure 4b).
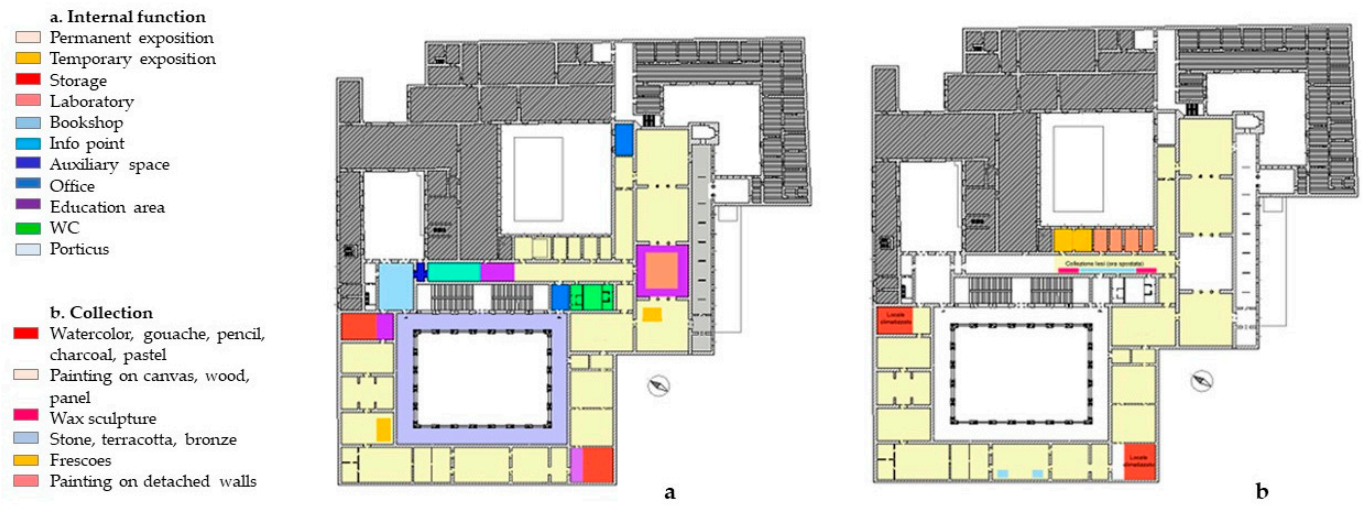

Figure 4. (a) internal building functions and (b) typology of objects of the Pinacoteca di Brera.

The conservation levels for each typology of artifacts are defined by national [31-33] and international [35-38] standards. Similarly, the comfort levels for each indoor activity refer to the existing literature and standards $[40,41,52]$. The compatibility between these requirements is reported below (Table 2). 
Table 2. Compatibility between preventive conservation and human comfort requirements [55].

\begin{tabular}{|c|c|c|c|c|}
\hline \multirow[b]{2}{*}{ Parameter } & \multirow[b]{2}{*}{ Specific Data } & \multicolumn{2}{|c|}{ Standard Requirements } & \multirow[b]{2}{*}{ Compatibility } \\
\hline & & $\begin{array}{c}\text { Preventive } \\
\text { Conservation }\end{array}$ & $\begin{array}{l}\text { Human } \\
\text { Comfort }\end{array}$ & \\
\hline \multirow{4}{*}{$\mathrm{E}[\mathrm{lux}]$} & Light-sensitive & $<50$ & & $\mathrm{I}$ \\
\hline & Less light-sensitive & $<200$ & $>300$ & $\mathrm{P}$ \\
\hline & Not light-sensitive & $>300$ & & $\mathrm{P}$ \\
\hline & Light-sensitive & $<30$ & & $\mathrm{~F}$ \\
\hline \multirow[t]{3}{*}{$\mathrm{UV}_{\max }[\mathrm{MW} / \mathrm{lm}]$} & Less light-sensitive & $<75$ & - & $\mathrm{F}$ \\
\hline & Not light-sensitive & $<200$ & & $\mathrm{~F}$ \\
\hline & Light-sensitive & $<200$ & & $\mathrm{~F}$ \\
\hline \multirow[t]{7}{*}{ EE [Kluxh/year] } & Less light-sensitive & $<650$ & - & $\mathrm{F}$ \\
\hline & Not light-sensitive & - & & $\mathrm{F}$ \\
\hline & & $0.5-2$ & $>2$ & $\mathrm{P}$ \\
\hline & & - & 1.15 & $\mathrm{~F}$ \\
\hline & & - & $3000-4000$ & $\mathrm{~F}$ \\
\hline & & - & $>85$ & $\mathrm{~F}$ \\
\hline & & $18-24$ & $20-26$ & $\mathrm{~F}$ \\
\hline \multirow{2}{*}{$\Delta \mathrm{T}_{\mathrm{a}}\left[{ }^{\circ} \mathrm{C}\right]$} & Daily & \pm 2 & - & $\mathrm{F}$ \\
\hline & Seasonal & \pm 9 & & $\mathrm{~F}$ \\
\hline \multirow{2}{*}{$\mathrm{T}_{\mathrm{o}}\left[{ }^{\circ} \mathrm{C}\right]$} & Winter & - & $18-20$ & $\mathrm{~F}$ \\
\hline & Summer & & $22-25$ & $\mathrm{~F}$ \\
\hline \multirow{2}{*}{$\mathrm{T}_{\mathrm{S}}\left[{ }^{\circ} \mathrm{C}\right]$} & On walls & - & $14-25$ & $\mathrm{~F}$ \\
\hline & On floors & - & $19-28$ & $\mathrm{~F}$ \\
\hline \multicolumn{2}{|c|}{$\mathrm{T}_{\mathrm{mr}}\left[{ }^{\circ} \mathrm{C}\right]$} & - & $17-21$ & $\mathrm{~F}$ \\
\hline \multicolumn{2}{|c|}{$\mathrm{RH}[\%]$} & $20-45$ & $35 \div 45$ & $\mathrm{P}$ \\
\hline \multirow{2}{*}{$\Delta \mathrm{RH}[\%]$} & Daily & $\pm 3- \pm 5$ & - & $\mathrm{F}$ \\
\hline & Seasonal & \pm 10 & - & $\mathrm{F}$ \\
\hline \multirow{7}{*}{$\begin{array}{l}\text { Gaseous pollutant } \\
\text { emissions }\end{array}$} & sec] & $0.1-0.25$ & - & $\mathrm{F}$ \\
\hline & $\mathrm{SO}_{\mathrm{x}}\left[\mathrm{mg} / \mathrm{m}^{3}\right]$ & $<10$ & & $\mathrm{~F}$ \\
\hline & $\mathrm{NO}_{x}\left[\mathrm{mg} / \mathrm{m}^{3}\right]$ & $<10$ & - & $\mathrm{F}$ \\
\hline & $\mathrm{O}_{3}\left[\mathrm{mg} / \mathrm{m}^{3}\right]$ & $<2$ & & $\mathrm{~F}$ \\
\hline & $\mathrm{CO}[\%]$ & - & $<0.003$ & $\mathrm{~F}$ \\
\hline & $\mathrm{CO}_{2}[\%]$ & - & $<0.15$ & $\mathrm{~F}$ \\
\hline & $\begin{array}{l}\text { naldehyde, formic acids, } \\
\text { enzene, } \mathrm{PM}_{10}\left[\mu \mathrm{g} / \mathrm{m}^{3}\right]\end{array}$ & - & - & $\mathrm{F}$ \\
\hline \multicolumn{2}{|c|}{ Solid contaminants [-] } & $\begin{array}{l}\text { Eff } 85 \% \text { on } \\
\text { Eurovent } 4 / 5\end{array}$ & - & $\mathrm{F}$ \\
\hline \multirow{2}{*}{\multicolumn{2}{|c|}{$\begin{array}{c}\mathrm{R}[\mathrm{l} / \mathrm{s} \text { people }] \\
\text { Microbes, bacteria and fungi }\left[\mathrm{CFU} / \mathrm{m}^{3}\right]\end{array}$}} & - & $>7.8$ & $\mathrm{~F}$ \\
\hline & & - & Absence & $\mathrm{F}$ \\
\hline \multicolumn{2}{|c|}{ Mold, pollen [-] } & - & Absence & $\mathrm{F}$ \\
\hline \multicolumn{2}{|c|}{ Pests [-] } & - & Absence & $\mathrm{F}$ \\
\hline \multicolumn{2}{|c|}{ Radon $\left[\mathrm{Bq} / \mathrm{m}^{3}\right]$} & - & - & $\mathrm{F}$ \\
\hline
\end{tabular}

$\mathrm{I}=$ Incompatibility $\mathrm{P}$ = Partial compatibility F = Full compatibility.

Several parameters show "full compatibility" (F) (Table 2) between heritage conservation and human comfort. On the contrary, E, $\mathrm{T}_{\mathrm{a}}$ and $\mathrm{RH}$ can be potential hazards as regards the "partial compatibility" (P) or the "incompatibility" (I) between the two requirements. To verify the possible risks, a deep study is realized on specific typologies of objects hosted in the Pinacoteca. The outcomes are presented below (Table 3), adding also the results of the LTM (Section 5.3). 
Table 3. Comparison between standard requirements and real long-term conditions for all the objects inserted in the Pinacoteca di Brera.

\begin{tabular}{|c|c|c|c|c|c|c|c|c|c|c|}
\hline \multirow{3}{*}{ Category of Object } & \multicolumn{7}{|c|}{ Standard Requirements for MPP } & \multirow{2}{*}{\multicolumn{3}{|c|}{$\begin{array}{l}\text { Real Conditions } \\
\text { (LTM) }\end{array}$}} \\
\hline & \multicolumn{4}{|c|}{ Conservation } & \multicolumn{3}{|c|}{ Human Comfort } & & & \\
\hline & $\begin{array}{l}E_{\max } \\
{[\operatorname{lux}]}\end{array}$ & $\begin{array}{c}\mathrm{UV}_{\max } \\
{[\mu \mathrm{W} / \mathrm{lm}]}\end{array}$ & $\begin{array}{c}\mathrm{T}_{\mathrm{a}} \\
{\left[{ }^{\circ} \mathrm{C}\right]}\end{array}$ & $\begin{array}{l}\text { RH } \\
{[\%]}\end{array}$ & $\begin{array}{l}E_{\min } \\
{[\operatorname{lux}]}\end{array}$ & $\begin{array}{c}\mathrm{T}_{\mathrm{a}} \\
{\left[{ }^{\circ} \mathrm{C}\right]}\end{array}$ & $\begin{array}{l}\text { RH } \\
{[\%]}\end{array}$ & $\begin{array}{c}E \\
{[\operatorname{lux}]}\end{array}$ & $\begin{array}{c}\mathrm{T}_{\mathrm{a}} \\
{\left[{ }^{\circ} \mathrm{C}\right]}\end{array}$ & $\begin{array}{l}\text { RH } \\
{[\%]}\end{array}$ \\
\hline $\begin{array}{l}\text { Watercolor gouache } \\
\text { pencil charcoal } \\
\text { pastel }\end{array}$ & 50 & 75 & $19-24$ & $45-60$ & \multicolumn{3}{|c|}{$\begin{array}{l}\text { Storage room: no } \\
\text { occupancy }\end{array}$} & 50 & 20 & 50 \\
\hline $\begin{array}{l}\text { Painting on canvas, } \\
\text { wood, panel }\end{array}$ & 150 & 75 & $19-24$ & $40-55$ & \multirow{6}{*}{$>300$} & \multirow{6}{*}{$19-26$} & \multirow{6}{*}{$45-55$} & 50 & $\begin{array}{l}16-21 \mathrm{~W} \\
25-30 \mathrm{~S}\end{array}$ & $\begin{array}{l}45-55 \mathrm{~W} \\
55-65 \mathrm{~S}\end{array}$ \\
\hline Wax sculpture & 150 & 75 & $<18$ & - & & & & $300-400$ & $20-24$ & $55-60$ \\
\hline Stone terracotta & - & - & $15-25$ & $20-60$ & & & & $300-400$ & $16-26$ & $55-60$ \\
\hline Bronze & - & - & $15-25$ & $20-60$ & & & & $300-400$ & $16-26$ & $55-60$ \\
\hline Frescoes & 150 & 75 & $10-24$ & $55-65$ & & & & $200-250$ & $22-24$ & $50-60$ \\
\hline $\begin{array}{c}\text { Painting on } \\
\text { detached walls }\end{array}$ & 150 & 75 & $10-24$ & $45-50$ & & & & 300 & $22-24$ & $50-55$ \\
\hline
\end{tabular}

$\mathrm{W}=$ Winter $\mathrm{S}=$ Summer.

The more fragile artefacts are watercolors, gouaches, pencils, pastels and charcoals on paper. Their conservation is completely opposite to the human comfort requirements. These artworks are conserved in storage rooms at controlled environmental conditions $\left(\mathrm{E}=50 \mathrm{lux} ; \mathrm{UV}_{\max }=75 \mathrm{MW} / \mathrm{lm}\right.$; $\mathrm{T}_{\mathrm{a}}=20^{\circ} \mathrm{C} ; \mathrm{RH}=50 \%$ ), and are accessible only by appointment. Thus, they are in safety conditions. Furthermore, precious paintings, constituted mainly by oil paintings (on panel, canvas, plywood, copper, paper, board), temperas (on paper and canvas) and mixed materials (e.g., wall paintings, frescoes detached and transferred to panels and canvas), are fragile artefacts. In this case, there are several risks mainly related to the standard light levels for conservation $(\mathrm{E}<150 \mathrm{lux})$ and human comfort ( $\mathrm{E}>300 \mathrm{lux})$. Wax sculptures also have thermal risks related to heritage protection $\left(\mathrm{T}_{\mathrm{a}}<18{ }^{\circ} \mathrm{C}\right)$ and human comfort $\left(\mathrm{T}_{\mathrm{a}}=20^{\circ} \mathrm{C}\right)$. On the contrary, inorganic objects (e.g., stone, marble, bronze and terracotta statues, vases, cenotaphs) have a high resistance to indoor conditions. For this reason, they can be placed freely along the museum, to create visual centers. For each typology of artworks, the areas with environmental risks for heritage conservation and human comfort conditions are evaluated (MPP). Here, an analytical study is necessary (analysis level, Section 5.3).

\subsection{Analysis Level}

STM of environmental conditions shows several problems. The original project of Piero Castiglioni (1994) focused on the integration of natural and artificial light. It was devoted to enhancing the aesthetic and chromatic qualities of the exhibition, through the introduction of electronic regulators and metal halide vapor lamps. To improve the visibility of artworks, he employed higher light levels than the conservative standards $[22,23,26,28]$, putting anti-UV and anti-IR filters on artefacts to guarantee their safeguard. The design project changed over the time, modifying the original criteria [71]. The STM conducted using the defined procedure (Section 4.3) confirmed the presence of E levels lightly greater than international standards [30,32]. The average value is 130 lux, lower than the standard requirements (150 lux), but several values are in the range $300-500$ lux. $\mathrm{T}_{\mathrm{a}}$ shows a stability in the range $20-22^{\circ} \mathrm{C}$, with an average value of $21{ }^{\circ} \mathrm{C}$. This thermal condition causes risks only for the wax collection (Table 3). On the contrary, there are several RH fluctuations, but in the range of $40-55 \%$ over the years. The hygrothermal levels for a typical day are shown below (Figure 5). 

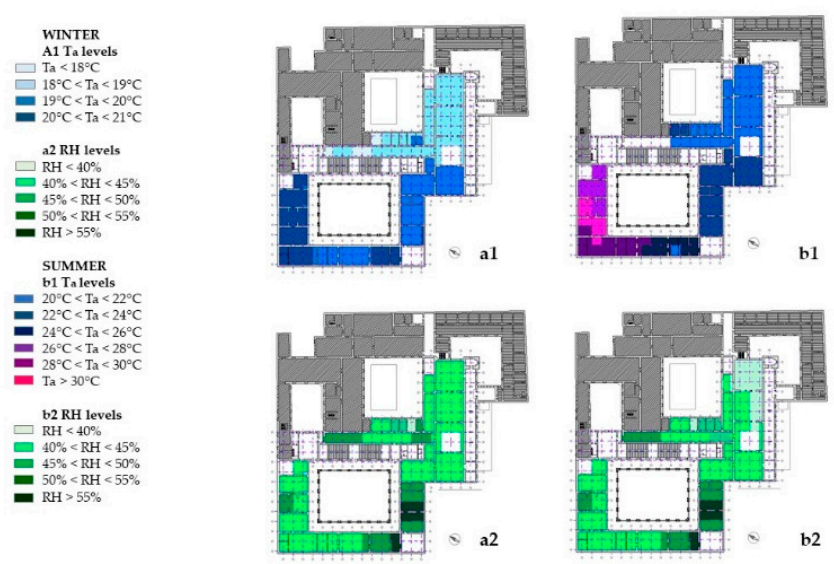

Figure 5. Results of short-term monitoring of $\mathrm{T}_{\mathrm{a}}$ and $\mathrm{RH}$ on a typical day in winter and summer.

In summer, the thermal values increase progressively from the entrance (rooms I-XII) to the last rooms (XXX-XXVIII) and, conversely, the hygrometric values decrease along the same path. The average $\mathrm{T}_{\mathrm{a}}$ in the first rooms is $20-21^{\circ} \mathrm{C}$, and the $\mathrm{RH}$ is around $55 \%$, optimal values both for safeguarding and comfort. The average $\mathrm{T}_{\mathrm{a}}$ in the last rooms is $30^{\circ} \mathrm{C}$, with peaks of $33^{\circ} \mathrm{C}$, and the $\mathrm{RH}$ is around $45-50 \%$. The opposite situation occurs in winter: $\mathrm{T}_{\mathrm{a}}$ decreases from the first (average $\mathrm{T}_{\mathrm{a}}=21^{\circ} \mathrm{C}$ ) to the last (average $\mathrm{T}_{\mathrm{a}}=18-19^{\circ} \mathrm{C}$ ) rooms. $\mathrm{RH}$ fluctuations depend on high fluxes of visitors and didactic activities. Three museum rooms have a "conservative risk" (rooms XXIV, XXXVI and XXXVII). LTM shows similar results to STM. E respects the international standard requirements ( $<150$ lux) [30,32], with average levels of 130-140 lux. Luminance monitoring, also supported by the comfort analysis, shows the absence of glare, thanks to the presence of window filters and anti-glare light sources. On the contrary, for a large part of the two years, hygrothermal conditions were beyond the standard ranges $\left(\mathrm{T}_{\mathrm{a}}=20^{\circ} \mathrm{C} ; \mathrm{RH}=50 \%\right)$ [32]. This data highlights the direct correlation between indoor and outdoor conditions, the number of visitors, management techniques and cleaning procedures. Average thermal data respect the standards [32]. In winter, average $\mathrm{T}_{\mathrm{a}}$ is $20^{\circ} \mathrm{C}$ (but with peaks of $18^{\circ} \mathrm{C}$ ), thanks to the presence of the HVAC system, and the daily fluctuation is $\pm 2{ }^{\circ} \mathrm{C}$. In summer, the average $\mathrm{T}_{\mathrm{a}}$ is $25^{\circ} \mathrm{C}$ (but with peaks of $33^{\circ} \mathrm{C}$ ), and the daily fluctuation is $\pm 2{ }^{\circ} \mathrm{C}$. On the contrary, seasonal fluctuation $\left(\Delta \mathrm{T}_{\mathrm{a}}= \pm 9^{\circ} \mathrm{C}\right)$ is higher than the standards $\left(\Delta \mathrm{T}_{\mathrm{a}}= \pm 2^{\circ} \mathrm{C}\right)$ [32]. The problem is more controlled in the first rooms $\left(\Delta \mathrm{T}_{\mathrm{a}}= \pm 2{ }^{\circ} \mathrm{C}\right)$ than the last ones $\left(\Delta \mathrm{T}_{\mathrm{a}}= \pm 8^{\circ} \mathrm{C}\right)$. This situation recurs seasonally. Despite this, the collection does not present thermal decay, like dilatation or craquelure. Autumn and winter seasons present the most important RH fluctuations, due to cleaning, managing and maintaining procedures. The high thickness of masonries and the presence of buffer zones favor RH stability, which varies only with external rain and visitors' fluxes (especially in the smaller rooms). $\mathrm{RH}$ is in the range $45 \% \pm 55 \%$ in winter, and $45 \% \pm 55 \%$ in summer. It never exceeds the standard threshold $(\mathrm{RH}<60 \%)$ for generating potential biological damage in the collection [32]. Daily and seasonal RH fluctuations are the maximum allowed by the standard [32], and respectively are $\pm 5 \%$ and $\pm 10 \%$. Portable humidifiers cause great indoor instability ( $\mathrm{RH}>60 \%)$. As expected, $\mathrm{CO}_{2}$ concentrations are higher at the weekend or holidays than during the week. The data reveals the correlation between $\mathrm{CO}_{2}$ concentration and the flux of visitors. In the following, the results of a typical week are shown (Figures 6 and 7). 


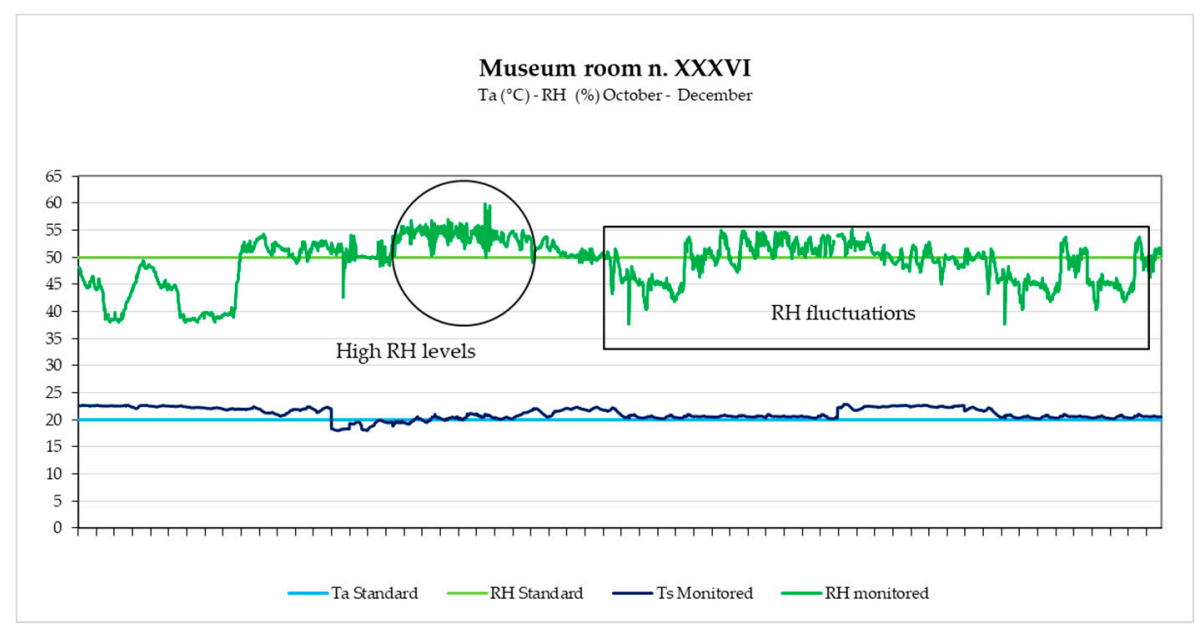

Figure 6. Portable humidifiers cause hygrometric instability as shown by long-term monitoring in a typical season (room n. XXXVI).

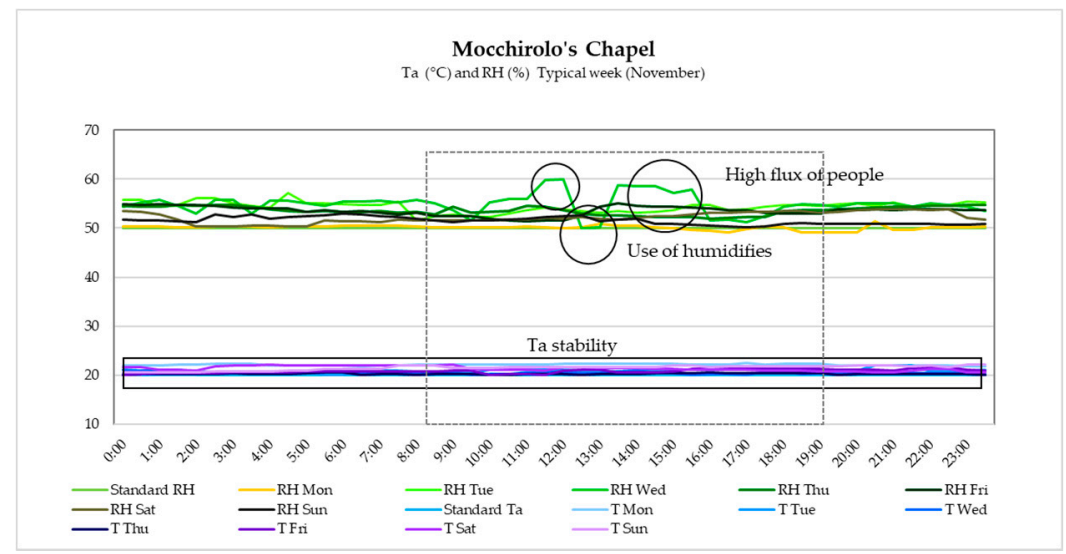

Figure 7. RH varies greatly while $\mathrm{T}_{\mathrm{a}}$ is stable, as shown by long-term monitoring in a typical week (Mocchirolo's Chapel, room n. Ia).

Comfort analysis reveals the presence of human discomfort, both in summer and winter. First, it shows the inadequacy of the visual comfort, because the natural and artificial lights do not emphasize the aesthetic and chromatic values of the collection. The most important criticisms concern the color of plasters and artificial lightings. Museum attendees remember the warm and diffuse light atmosphere created by the previous "Brera yellow" plaster. The actual mat and white plaster changes completely this original atmosphere, creating monotone tones in some rooms. Red and green plasters have a better impact on the visitors' perception. Similarly, the replacement of the fluorescent lamps with high efficiency spots improves their energy performances, also modifying the users' perception. The actual light sources appear too cold and uniform along the exhibition. The international visitors suggest creating visual centers for the masterpieces, to accentuate their tonalities. The staff also reveal a thermal discomfort. In winter, the presence of low $\mathrm{T}_{\mathrm{a}}$ forces them to work with a coat on, while in summer, $\mathrm{T}_{\mathrm{a}}$ appears too high, especially in the last rooms. This situation is confirmed by the LTM. No acoustic comfort is detected thanks to the presence of a green patio (Table 4). 
Table 4. Results of the comfort analysis in the Pinacoteca di Brera.

\begin{tabular}{|c|c|c|c|}
\hline \multirow{2}{*}{ Type of User } & \multirow{2}{*}{ Rooms } & \multicolumn{2}{|c|}{ Problems Point Out in the Comfort Analysis } \\
\hline & & Summer & Winter \\
\hline \multirow{4}{*}{ Museum attendants } & $\mathrm{I}-\mathrm{XV}$ & $\begin{array}{l}\text { Thermal } \\
\text { High therma }\end{array}$ & $\begin{array}{l}\text { mfort } \\
\text { xcursion }\end{array}$ \\
\hline & \multirow{3}{*}{ XVI-XXIX } & $\begin{array}{c}- \\
\text { High } \mathrm{T}_{\mathrm{a}} \text { and } \mathrm{RH} \\
\text { Insufficient ventilation }\end{array}$ & $\begin{array}{c}\text { High RH } \\
\text { Thermal comfort } \\
\text { High thermal excursion }\end{array}$ \\
\hline & & \multicolumn{2}{|c|}{$\begin{array}{c}\text { High thermal excursion } \\
\text { High RH } \\
\text { Perception of absence of HVAC systems }\end{array}$} \\
\hline & & $\begin{array}{l}\text { Unbeatable } \mathrm{T}_{\mathrm{a}} \\
\text { Insufficient ventilation }\end{array}$ & $\begin{array}{c}\text { Low } \mathrm{T}_{\mathrm{a}} \\
-\end{array}$ \\
\hline & & \multicolumn{2}{|c|}{ No visual comfort } \\
\hline National museum visitors & Entire museum & $\begin{array}{l}\text { High thermal excursion } \\
\text { High } \mathrm{T}_{\mathrm{a}} \\
\text { Excessively uniform } \mathrm{E}\end{array}$ & $\begin{array}{c}\text { Hygrothermal comfort } \\
- \\
-\end{array}$ \\
\hline International museum visitors & Entire museum & $\begin{array}{c}\text { High } \mathrm{T}_{\mathrm{a}} \\
\text { Absence of visual comfort } \\
\text { Not enhanced visual impact }\end{array}$ & $\begin{array}{l}\text { Hygrothermal comfort } \\
\text { Visual comfort } \\
\text { Low E }\end{array}$ \\
\hline
\end{tabular}

\subsection{Expertise Level}

The "expertise level" permits us to identify guidelines and suggestions for solving specific problems in preventive conservation and human comfort. Basically, there is no irremediable contrast between protection and accessibility. The old palace has a suitable geometric and constructive profile for hosting a museum building, thanks to the presence of compact shapes, high thermal resistance and the inertia of the building envelope, the buffer spaces for protecting the museum rooms (i.e., passages, patios, green yards) and possible cross-ventilation strategies. The opaque building envelope (walls and ceilings) is typical of northern Italy, with brick masonries with high thickness $(0.80 \mathrm{~m})$. The qualitative infrared (hereinafter, IR) thermography shows the presence of thermal uniformity and reduced thermal bridges, as well as the absence of water infiltrations. Windows and curtain glasses, despite their replacement in 1980, are subject to thermal losses and air leakage. It is necessary to perform an energy audit for evaluating the most appropriate interventions (i.e., sealing, insertion of a well-isolated curtain or a low-emissivity coating, replacement with new systems with better performances, air permeability, and UV protection). No bioclimatic design based on natural light and ventilation control has been studied during the various refurbishments. The implementation of these passive measures can guarantee an adequate environmental performance for heritage conservation and human comfort. Additionally, portable humidifiers regulate the hygrometric fluctuations via the intervention of the museum attendants. Some rooms have higher indoor RH fluctuations than the conservative standards [32] (Section 5.3). RH variability is caused mainly by the presence of portable humidifiers, the flux of people, and cleaning procedures. The humidifiers are not always necessary for conservative policies, besides having high energy consumption. Thus, it is recommended to switch them on only with low $\mathrm{RH}$ levels ( $\mathrm{RH}<30-35 \%$ ), in order to not generate hygrometric damage and biodegradation (e.g., presence of microorganisms, wet-corrosion, moisture in walls) [32]. The use of water in the cleaning procedures should also be reduced. An energy audit is recommended to evaluate the most appropriate measures for controlling $\mathrm{T}_{\mathrm{a}}$ and $\mathrm{RH}$. The electric system is safe from risks (Section 5.1). Lighting has discrete energy performances, guaranteed by daylight integration, the choice of lamps, and periodic maintenance. On the contrary, the comfort analysis demonstrates several visual discomforts linked to the chromatic and lighting design (Section 5.3). Numerous low-engineering interventions can be suggested. First, it is not opportune to reduce $\mathrm{E}$ to favor human comfort, as people lament the difficulty in seeing the objects. To minimize potential photochemical alteration, it is necessary to reduce the annual "energy exposure level" with the rotation of artifacts, 
or the insertion of IR control system for switching on the light only with people present. It is also better to check periodically the performance of UV and IR filters with the support of visual analyses and monitoring devices. International visitors suggest creating new visual centers, to emphasize the masterpieces with a specific chromatic and lighting design. Museum attendants propose recreating the original chromatic atmosphere, using warm plasters and light sources in the same color tones as the artworks. A separate discussion refers to murals and frescoes inserted in Mocchirolo's and San Giuseppe's Chapels, which require limited E and perfect climate stability. The daily and weekly $\mathrm{T}_{\mathrm{a}}$ are quite stable, while the RH has high weekly fluctuations. Regulation of the visits is useful to plan a separate climatic control. The main problems of the Pinacoteca depend on the progress of the conservation science, especially related to management procedures, planning regulations and financial resources. In most cases, the conservative issues are due to the fragmentary modification of the exhibits in different historical periods, to solve localised and contingent efforts. Additionally, the hygrothermal monitoring shows a strict link between $\mathrm{RH}$ fluctuations, clearing procedures and the fluctuations of visitors (Section 5.3). In this case, specific training can be done for the museum staff, to explicate the correct procedure to be adopted. Low-engineering interventions to reduce this problem include the daily analysis of RH fluctuations, the correct use of the portable humidifiers, the adoption of cleaning procedures without water, and the regulation of touristic and group visits. Furthermore, the building needs continuous commissioning, to verify the existence of appropriate energy and environmental conditions [14]. Finally, a museum conservation program can be useful to explicate in a clear way the internal environmental recommendations for the attendants. Below, the issues detected, comparing the original and current layout, are summarized (Table 5).

Table 5. Environmental risks and possible recommendations related to the modifications of the original design by Portaluppi and Albini.

\begin{tabular}{|c|c|c|c|c|}
\hline Original Design & Modifications & $\begin{array}{l}\text { Environmental } \\
\text { Risks }\end{array}$ & Recommendations & Adjunctive Tests \\
\hline \multirow{7}{*}{$\begin{array}{l}\text { Replacement of the } \\
\text { original skylights }\end{array}$} & \multirow{7}{*}{$\begin{array}{l}\text { Replacement of } \\
\text { curtains and } \\
\text { skylights with } \\
\text { glass-chamber and } \\
\text { UV-filters }\end{array}$} & $\begin{array}{l}\text { High heat loss and } \\
\text { air infiltrations } \\
\text { from skylights }\end{array}$ & $\begin{array}{l}\text { To seal the skylights } \\
\text { To insert a well-isolated } \\
\text { curtain or a low-emissivity } \\
\text { coating on skylights } \\
\text { To perform an energy audit }\end{array}$ & $\begin{array}{l}\text { Blower door test } \\
\text { (BDT) } \\
\text { IR-thermography } \\
\text { (IRT) }\end{array}$ \\
\hline & & \multirow{5}{*}{$\begin{array}{l}\text { Non-filtered air } \\
\text { from windows }\end{array}$} & $\begin{array}{l}\text { To verify the pollutant } \\
\text { concentration }\end{array}$ & \multirow{5}{*}{$\begin{array}{l}\text { Pollutant } \\
\text { concentration } \\
\text { monitoring }\end{array}$} \\
\hline & & & To keep surfaces clean & \\
\hline & & & $\begin{array}{l}\text { To use dust covers without } \\
\text { visitors }\end{array}$ & \\
\hline & & & $\begin{array}{l}\text { To evaluate the pollution } \\
\text { filtering in HVAC }\end{array}$ & \\
\hline & & & $\begin{array}{l}\text { To use portable air-filters with } \\
\text { activate carbon filters }\end{array}$ & \\
\hline & & $\begin{array}{l}\text { High E for } \\
\text { conservation } \\
\text { standards }\end{array}$ & $\begin{array}{l}\text { To not reduce E } \\
\text { To reduce EE respecting the } \\
\text { conservative standards } \\
\text { To verify UV } U_{\max } \\
\text { To verify the conservation } \\
\text { state of UV filters } \\
\text { To replace UV-filters where is } \\
\text { necessary } \\
\text { To reduce EE using shutters or } \\
\text { filters }\end{array}$ & $\begin{array}{l}\text { Visual analysis } \\
\text { UV and IR } \\
\text { monitoring }\end{array}$ \\
\hline \multirow[t]{2}{*}{$\begin{array}{l}\text { Closure of all } \\
\text { windows }\end{array}$} & $\begin{array}{l}\text { Opening of the } \\
\text { existing windows }\end{array}$ & $\begin{array}{l}\text { Visual discomfort } \\
\text { Low E for human } \\
\text { comfort }\end{array}$ & $\begin{array}{l}\text { To rotate the artworks between } \\
\text { museum and storage rooms }\end{array}$ & $\begin{array}{l}\mathrm{E} \text { and } \mathrm{T}_{\mathrm{a}} \\
\text { monitoring }\end{array}$ \\
\hline & & & To use window coverings & \\
\hline
\end{tabular}


Table 5. Cont.

\begin{tabular}{|c|c|c|c|c|}
\hline Original Design & Modifications & $\begin{array}{l}\text { Environmental } \\
\text { Risks }\end{array}$ & Recommendations & Adjunctive Tests \\
\hline $\begin{array}{l}\text { Opening of vaults } \\
\text { in the entrance hall }\end{array}$ & - & $\begin{array}{l}\text { High E for } \\
\text { conservation }\end{array}$ & $\begin{array}{l}\text { To not reduce E } \\
\text { To reduce EE } \\
\text { To rotate the artworks between } \\
\text { museum and storage rooms }\end{array}$ & E monitoring \\
\hline $\begin{array}{l}\text { Refurbishment of } \\
\text { the roof }\end{array}$ & - & No problem & - & - \\
\hline $\begin{array}{l}\text { Wall plastering } \\
\text { (bright yellow } \\
\text { plaster) }\end{array}$ & $\begin{array}{l}\text { New wall } \\
\text { plastering }\end{array}$ & $\begin{array}{l}\text { Too uniform } \\
\text { luminance }\end{array}$ & $\begin{array}{l}\text { To create visual centers } \\
\text { To emphasize the masterpieces } \\
\text { with chromatic design }\end{array}$ & $\begin{array}{l}\text { Questionnaires, } \\
\text { POE }\end{array}$ \\
\hline $\begin{array}{l}\text { Selection of } \\
\text { decorative } \\
\text { materials }\end{array}$ & - & No problem & $\begin{array}{l}\text { To create esthetic centers on } \\
\text { these materials }\end{array}$ & - \\
\hline \multirow{2}{*}{$\begin{array}{l}\text { Insertion of } \\
\text { fluorescent light } \\
\text { sources }\end{array}$} & \multirow{2}{*}{$\begin{array}{l}\text { Replacement of } \\
\text { original sources } \\
\text { with halide lamps } \\
\text { Addition of } \\
\text { electronic } \\
\text { regulators }\end{array}$} & $\begin{array}{l}\text { High E for } \\
\text { conservation } \\
\text { standards }\end{array}$ & $\begin{array}{l}\text { To not reduce E } \\
\text { To reduce EE } \\
\text { To reduce the display time for } \\
\text { fragile artefacts } \\
\text { To define the maximum EE for } \\
\text { each artefact }\end{array}$ & E monitoring \\
\hline & & $\begin{array}{l}\text { Thermal } \\
\text { fluctuations on } \\
\text { objects }\end{array}$ & $\begin{array}{l}\text { To verify } \mathrm{T}_{\mathrm{a}} \text { fluctuations on } \\
\text { high sensible artifacts } \\
\text { To check anti-IR filter on the } \\
\text { lamps } \\
\text { To use low-T lamps } \\
\text { To use external or integrate } \\
\text { lamps in display-cases }\end{array}$ & $\begin{array}{l}\text { Indoor } \mathrm{T}_{\mathrm{a}} \\
\text { monitoring }\end{array}$ \\
\hline \multirow[t]{2}{*}{ HVAC systems } & \multirow[t]{2}{*}{$\begin{array}{l}\text { Several } \\
\text { modifications }\end{array}$} & $\begin{array}{l}\text { High seasonal } \Delta \mathrm{T}_{\mathrm{a}} \\
\text { fluctuation for } \\
\text { conservative } \\
\text { standards }\end{array}$ & $\begin{array}{l}\text { To valorize the original } \\
\text { building features } \\
\text { To check HVAC system } \\
\text { periodically }\end{array}$ & $\mathrm{T}_{\mathrm{a}}$ monitoring \\
\hline & & $\begin{array}{l}\text { Overheating and } \\
\text { high } T_{a} \text { in summer }\end{array}$ & $\begin{array}{l}\text { To verify the benefits of } \\
\text { cross-ventilation strategies }\end{array}$ & $\begin{array}{l}\text { Questionnaire, } \\
\text { POE }\end{array}$ \\
\hline $\begin{array}{l}\text { Absence of } \\
\text { hygrometric project }\end{array}$ & $\begin{array}{l}\text { Insertion of } \\
\text { portable } \\
\text { humidifiers }\end{array}$ & High RH level & $\begin{array}{l}\text { To define clear guidelines with } \\
\text { RH levels for each typology of } \\
\text { object } \\
\text { To evaluate the use of active } \\
\text { RH regulation systems }\end{array}$ & $\begin{array}{l}\text { RH indoor } \\
\text { monitoring }\end{array}$ \\
\hline
\end{tabular}


Table 5. Cont.

\begin{tabular}{lllll}
\hline \multicolumn{1}{c}{ Original Design } & Modifications & \multicolumn{1}{c}{$\begin{array}{c}\text { Environmental } \\
\text { Risks }\end{array}$} & Recommendations & Adjunctive Tests \\
\hline $\begin{array}{l}\text { New storage room } \\
\begin{array}{l}\text { without climate } \\
\text { control }\end{array}\end{array}$ & $\begin{array}{l}\text { Addition of climate } \\
\text { control storages }\end{array}$ & No problem & - & - \\
\hline $\begin{array}{l}\text { Reconstruction of } \\
\text { the Mocchirolo's } \\
\text { Chapel }\end{array}$ & $\begin{array}{l}\text { New lighting } \\
\text { design }\end{array}$ & High E level & To reduce EE & $\begin{array}{l}\text { E, } \mathrm{T}_{\mathrm{a},} \text { RH } \\
\text { monitoring } \\
\text { Questionare, POE }\end{array}$ \\
\cline { 2 - 5 } $\begin{array}{l}\text { Absence of } \\
\text { conservation } \\
\text { program }\end{array}$ & $\begin{array}{l}\text { Internal } \\
\text { conservation policy }\end{array}$ & No problem & To add energy policies in MPP & - \\
\hline
\end{tabular}

\section{Conclusions}

The research presents an operative instrument for evaluating the environmental risks in complex museums located in historic buildings. This SOBANE approach suggests a strategic and repeatable methodology for conserving and enhancing the cultural heritage, recognizing that the project is not limited to the building design, but it requires maintenance and preventive conservation actions over time: "[ ... ] achieving appropriate environmental conditions is one thing. Sustaining these conditions is often another matter" ([14] p. 39). This method is applied to the Pinacoteca di Brera in Milan, to validate its suitability in a real case study with the support of museum attendants. This innovative approach can be easily applicable to other museums located in historic and existing buildings, independently of the building features (i.e., typology, age, architectonic style), and the type of collection (i.e., art museums, archeologic museums, historic house museum, history or living history museums, encyclopedic museums, science museums or natural history museums). Furthermore, this decision-making process can be adapted to local legislative frameworks, policies and management procedures. The present approach suggests an easy and accessible corpus operandi: (i) to assess the energy and environmental quality; (ii) to check the possible risks; (iii) quantify the factors responsible for damage phenomena; (iv) to select the most appropriate interventions to improve the conservation state; and (v) to program correct retrofit solutions. The immediate benefits of employing this SOBANE approach for environmental risk management in museums include:

- Efficient decision-making process for the risk assessment in museum buildings;

- Progressive approach based on simple steps (at the end of each level, the operative staff decides whether to pursue the investigations at the subsequent level);

- Immediate validation of ideas or concepts for each single step;

- Lower cost and reduced time for its development;

- Application of a co-design approach that favors collaboration with interdisciplinary skills and knowledge to generate original ideas and interventions;

- Better cooperation between different people and organizations, and across disciplines;

- Improved knowledge of museum attendants and visitors.

The long-term benefits include:

- Planning of comprehensive retrofit interventions, aimed not only at solving specific problems and urgent risks;

- Cost-efficient planning of the refurbishment, based on the available financial resources, and devoted to the reduction of logistical problems, timing and the cost of single actions;

- Definition of low-engineering interventions, based on vigilance, effective maintenance, managerial training and motivation of the staff. These interventions are not considered in a traditional refurbishment process; 
- Introduction of correct and continuative maintenance procedures, essential to prevent decay, discomfort and the malfunction of systems;

- Development of a risk management plan as a continuous process for adjusting and monitoring the interventions;

- Improved interest and participation in museum attendants that became conscious of the importance of their role for care and environmental sustainability;

- Introduction of ad hoc training activities for the museum attendants.

This experience also shows that a widespread knowledge of the state of the art of the museum must be considered for the success of environmental risk management. Furthermore, participatory actions with museum attendants are important mechanisms for improving their awareness of daily management and maintenance.

Funding: This research received no external funding.

Acknowledgments: This work was done during the research fellowship in the Politecnico di Milano. The author thanks the museum attendants, conservators, curators and heritage authorities for the fruitful exchange on the risk management of heritage buildings and collections.

Conflicts of Interest: The authors declare no conflict of interest.

\section{Nomenclature}

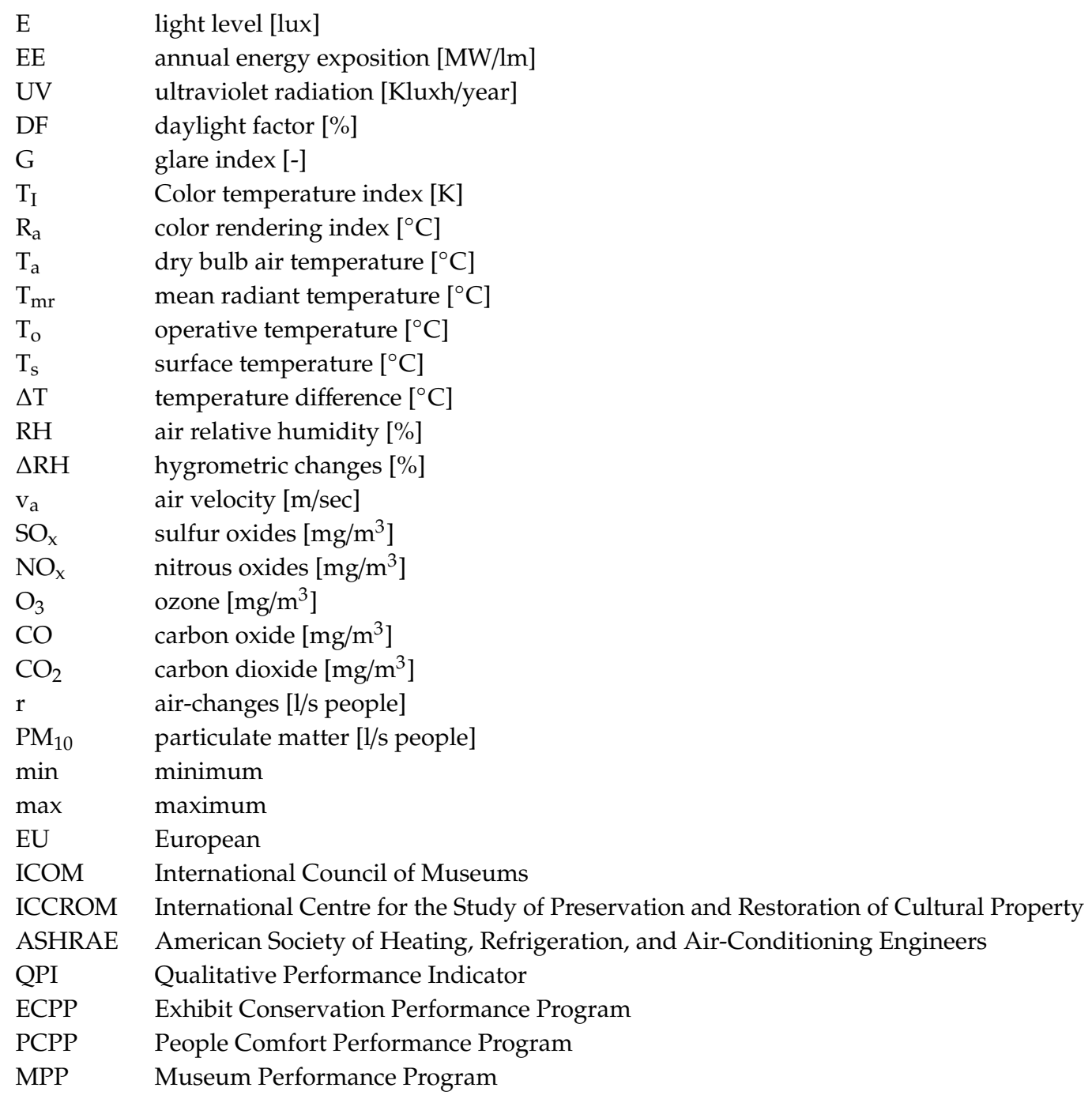




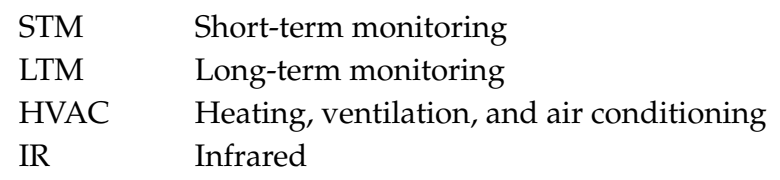

\section{References}

1. ICOM (International Council of Museums). ICOM Statutes; ICOM: Vienna, Austria, 2007.

2. Council of Europe. Council of Europe Framework Convention on the Value of Cultural Heritage for Society, CETS No. 199. 2005. Available online: http://conventions.coe.int/Treaty/EN/Treaties/Html/199.htm (accessed on 21 December 2019).

3. Council of Europe. Action Plan for the Promotion of the Faro Framework Convention on the Value of Cultural Heritage for Society 2013-2015, AT 510/2014. 2014. Available online: www.coe.int/t/dg4/cultureheritage/ heritage/identities/AT-2014-510-Faro-AP_en.pdf (accessed on 21 December 2019).

4. Cerquetti, M. More is better! Current issues and challenges for museum audience development: A literature review. ENCATC J. Cult. Manag. Policy 2016, 6, 2224-2554.

5. Douglas, D. The Museum Transformed: Design and Culture in the Post-Pompidou Age; Abbeville Press: New York, NY, USA, 1990.

6. Janes, R.; Conaty, G. Looking Reality in the Eye: Museums and Social Responsibility; University of Calgary Press: Calgary, AB, Canada, 2005.

7. Dindler, C. Designing infrastructures for creative engagement. Dig. Creat. 2014, 25, 212-223. [CrossRef]

8. Hooper-Greenhill, E. Changing values in the art museum: Rethinking communication and learning. Int. J. Herit. Stud. 2000, 6, 9-31. [CrossRef]

9. Tombazis, A.N. Guidelines for the Design and Retrofitting of Energy Efficient Museums for Antiquities in the Mediterranean Countries; Kakkizas: Athens, Greece, 1999.

10. Tombazis, A.N. Retrofitting of Museums for Antiquities in the Mediterranean Countries; Case Study: The Archeological Museum of Delphi, Kakkizas: Athens, Greece, 1998.

11. Avrami, E. The Conservation Assessment: A Proposed Model for Evaluating Museum Environmental Management Needs; The Getty Conservation Institute: Los Angeles, CA, USA, 1999.

12. Camuffo, D. Microclimate for Cultural Heritage; Elsevier: Amsterdam, The Netherlands, 2019.

13. Carbonara, G. An Italian contribution to architectural restoration. Front. Arch. Res. 2012, 1, 2-9. [CrossRef]

14. Cassar, M. (Ed.) Museums Environment Energy; HMSO: London, UK, 1994.

15. ICCROM (International Centre for the Study of Preservation and Restoration of Cultural Property). Teamwork for Preventive Conservation; ICCROM: Roma, Italy, 2004.

16. National Park Service (NPS). Museum Handbook; NPS: Washington, DC, USA, 1999.

17. Consiglio Superiore per le Antichità e Belle Arti. Carta Italiana del Restauro; Consiglio Superiore: Roma, Italy, 1931.

18. International Council on Monuments and Sites (ICOMOS). The Athens Charter for the Restoration of Historic Monuments. In Proceedings of the First International Congress of Architects and Technicians of Historic Monuments, Athens, Greece; 1931. Available online: www.icomos.org/en/167-the-athens-charter-for-therestoration-of-historic-monuments (accessed on 21 December 2019).

19. International Council on Monuments and Sites (ICOMOS). International Charter for the Conservation and Restoration of Monuments and Sites (The Venice Charter). In Proceedings of the IInd International Congress of Architects and Technicians of Historic Monuments, Venice, Italy, 25-31 May 1964.

20. Plenderlith, H.J. The Conservation of Antiquities and Works of Art: Treatment, Repair, and Restoration. Libr. Q. Inf. Commun. Policy 1958, 4, 46-54.

21. ICCROM (International Centre for the Study of Preservation and Restoration of Cultural Property). Museum Conservation: Lighting; ICCROM: Roma, Italy, 1975.

22. ICOM (International Council of Museums). La Lumière et la Protection des Objets et Spécimens Exposés Dans les MUSÉES et Galeries d'Art; ICOM: Paris, France, 1971.

23. Thomson, G. The Museum Environment; Butterworths: London, UK, 1978.

24. Stolow, N. Conservation Standards for Works of Art in Transit and on Exhibition, Museums and Monuments; Unipub: Paris, France, 1979. 
25. Banks, J.M. Guidelines for Preventive Conservation; Committee on Conservation/Preservation of Library Materials: Ottawa, ON, Canada, 1981.

26. CIBSE (Chartered Institution of Building Services Engineers). Lighting for Museum and Galleries; CIBSE: Paris, France, 1994.

27. Cassar, M. Environmental Management: Guidelines for Museums and Galleries; Routledge: London, UK; New York, NY, USA, 1995.

28. IESNA (Illuminating Engineering Society of North America). Lighting Handbook; IESNA: New York, NY, USA, 2000.

29. Blades, N.; Oreszczyn, T.; Cassar, M.; Bordass, W. Guideline on Pollution Control in Museum Buildings; Museums Association: London, UK, 2000; p. 15.

30. CIE (Commission Internationale de l'Eclairage). CIE 157. Technical Report Control of Damage to Museum Objects by Optical Radiation; CIE: Paris, France, 2004.

31. Ente Nazionale Italiano di Unificazione (UNI). Condizioni Climatiche per Ambienti di Conservazione di Documenti Grafici e Caratteristiche Degli Alloggiamenti, Standard UNI 10586; UNI: Milano, Italy, 1999.

32. Ente Nazionale Italiano di Unificazione (UNI). Beni di Interesse Storico Artistico. Condizioni Ambientali di Conservazione. Misure ed Analisi, Standard UNI 10829; UNI: Milano, Italy, 1999.

33. Ente Nazionale Italiano di Unificazione (UNI). Principi Generali per la Scelta e il Controllo del Microclima per la Conservazione, Beni Culturali, Standard UNI 10969; UNI: Milano, Italy, 2002.

34. European Committee for Standardization (CEN). Indoor Environmental Parameters for Assessment of Energy Performance of Buildings, Addressing Indoor Air Quality, Thermal Environment, Lighting and Acoustics, Standard EN 15251; CEN: Brussels, Belgium, 2007.

35. European Committee for Standardization (CEN). Conservation of Cultural Property. Specifications for Temperature and Relative Humidity to Limit Climate-Induced Mechanical Damage in Organic Hygroscopic Materials, Standard EN 15757; CEN: Brussels, Belgium, 2010.

36. European Committee for Standardization (CEN). Conservation of Cultural Property. Procedures and Instruments for Measuring Temperatures of the Air and the Surfaces of Objects, Standard EN 15758; CEN: Brussels, Belgium, 2010.

37. European Committee for Standardization (CEN). Conservation of Cultural Property. Indoor climate, Standard EN 15759; CEN: Brussels, Belgium, 2011.

38. European Committee for Standardization (CEN). Conservation of Cultural Heritage. Procedures and Instruments for Measuring Humidity in the Air and Moisture Exchanges between Air and Cultural Property, Standard EN 16242; CEN: Brussels, Belgium, 2012.

39. European Committee for Standardization (CEN). Conservation of Cultural Heritage. Guidelines and Procedures for Choosing Appropriate Lighting for Indoor Exhibitions, Standard CEN/TS 16163; CEN: Brussels, Belgium, 2014.

40. Museum \& Galleries Commission. Standards in the Museum Care of Archaeological Collections; Museums \& Galleries Commission: London, UK, 1992.

41. Service Archéologique Departmental des Yvelines. L'actualité de la Conservation-Restauration en Archéologie: Produits et Techniques, Conservation Preventive; ARAAFU: Paris, France, 1998.

42. Canadian Conservation Institute (CCI). Preventive Conservation in Museums; Universite du Quebec: Montreal, QC, Canada, 1995.

43. Cassar, M.; Hutchings, J. Relative Humidity and Temperature Pattern Book. A Guide to Understanding and Using Data on the Museum Environment; Museums\&Galleries Commission: London, UK, 2000.

44. Tétreault, J. Airborne Pollutants in Museums, Galleries, and Archives: Risk Assessment, Control Strategies, and Preservation Management; Canadian Conservation Institute: Ottawa, ON, Canada, 2003.

45. Michalski, S.; Grattan, D. Environmental Guidelines for Museums; Canadian Conservation Institute: Ottawa, ON, Canada, 2010.

46. Heritage Collection Council (HCC). Guidelines for Environmental Control in Cultural Institutions; HCC: Canberra, Australia, 2002.

47. Lucchi, E. Review of preventive conservation in museum buildings. J. Cult. Herit. 2018, 29, 180-183. [CrossRef]

48. ASHRAE (American Society of Heating, Refrigerating and Air-Conditioning Engineers); Museums, Galleries, Archives, and Libraries, in ASHRAE (Eds.) ASHRAE Handbook: Heating, Ventilating, and Air-Conditioning Applications; ASHRAE: Atlanta, Georgia, 2015; p. 23. 
49. Padfield, T. The role of standards and guidelines. are they a substitute for understanding a problem or protection against the consequences of ignorance? In Durability and Change; Krumbein, W.E., Ed.; Wiley: Copenhagen, Denmark, 1994; pp. 191-199.

50. CEN/TC 346 (2009-2014). Conservation of Cultural Heritage; European Committee for Standardization: Brussels, Belgium; Available online: https://standards.iteh.ai/catalog/tc/cen/782ad083-d5d4-4d4f-ac6d-36572d262c15/ cen-tc-346 (accessed on 21 December 2019).

51. New Orleans Charter for the Joint Preservation of Historic Structures and Artefacts. Available online: www.culturalheritage.org (accessed on 21 December 2019).

52. Luciani, A. Historical Climates and Conservation Environments. Historical Perspectives on Climate Control Strategies within Museum and Heritage Buildings. Ph.D. Thesis, Politecnico di Milano, Milano, Italy, 2013.

53. ICCROM (International Centre for the Study of Preservation and Restoration of Cultural Property). A Guide to Risk Management of Cultural Heritage; ICCROM: Sharjah, UAE, 2016.

54. Ankersmit, B.; Stappers, M.H.L. Managing Indoor Climate Risks in Museums; Springer: Basel, Switzerland, 2016.

55. Lucchi, E. Multidisciplinary risk-based analysis for supporting the decision-making process on conservation, energy efficiency, and human comfort in museum buildings. J. Cult. Herit. 2018, 22, 1079-1089. [CrossRef]

56. Malchaire, J. The SOBANE risk management strategy and the Dèparis method for the participatory screening of the risks. Int. Arch. Occup. Environ. Health 2004, 77, 443-450. [CrossRef] [PubMed]

57. Wirilander, H. Preventive Conservation: A Key Method to Ensure Cultural Heritage's Authenticity and Integrity in Preservation Process, Connaissances et reconnaissance du conservateur-restaurateur. CeROArt 2012, 6.

58. Padfield, T.; Borchersen, K. Museum Microclimates; The National Museum of Denmark: Copenhagen, Denmark, 2007.

59. Kuzucuoglu, A.H. Risk management in libraries, archives and museums. IIB Int. Ref. Accad. Soc. Sci. J. 2014, 15, 277-294.

60. Vranikas, N.; Kosmopoulos, P.; Papadopoulos, A.M. Management of museums' indoor environment: An interdisciplinary challenge. Adv. Build. Energy Res. 2011, 5, 43-51. [CrossRef]

61. Ashley-Smith, J. Risk Assessment for Object Conservation; Routledge: London, UK; New York, NY, USA, 2011.

62. Staniforth, S. Environmental conditions for the safeguarding of collections: Future trends. Stud. Conserv. 2014, 59, 213-217. [CrossRef]

63. Živković, V.; Džikić, V. Return to basics. Environmental management for museum collections and historic houses. Energy Build. 2015, 95, 116-123. [CrossRef]

64. D'Agostino, V.; Alfano, F.R.D.A.; Palella, B.I.; Riccio, G. The museum environment: A protocol for evaluation of microclimatic conditions. Energy Build. 2015, 95, 124-129. [CrossRef]

65. Ferdyn-Grygierek, J. Indoor environment quality in the museum building and its effect on heating and cooling demand. Energy Build. 2014, 85, 32-44. [CrossRef]

66. Entradas Silva, H.; Henriques, F.M.; Henriques, T.A.; Coelho, G. A sequential process to assess and optimize the indoor climate in museums. Build. Environ. 2016, 104, 21-34. [CrossRef]

67. International Organization for Standard (ISO). Risk Management: Guidelines, Standard ISO 31000; ISO: Brussels, Belgium, 2018.

68. Lucchi, E. Simplified assessment method for environmental and energy quality in museum buildings. Energy Build. 2016, 117, 216-229. [CrossRef]

69. Arrigoni, L.; Bandera, S. (Eds.) La Pinacoteca di Brera; Skira: Milano, Italy, 2010.

70. Matalon, S. La Pinacoteca di Brera a Milano; Garzanti: Milano, Italy, 1952.

71. Tardito, R. Brera. Storia Della Pinacoteca e Delle Sue Collezioni; Editoriale Cantini: Milano, Italy, 1986.

72. Watson, C. Review of building quality using post occupancy evaluation, PEB Exchange. J. Programme Educ. Build. 2003, 48, 15-18.

73. SIRBec-Sistema Informativo dei Beni Culturali di Regione Lombardia. Available online: www. lombardiabeniculturali.it (accessed on 21 December 2019).

(C) 2020 by the author. Licensee MDPI, Basel, Switzerland. This article is an open access article distributed under the terms and conditions of the Creative Commons Attribution (CC BY) license (http://creativecommons.org/licenses/by/4.0/). 